\title{
Citizenship, Democracy and the Transformation of Public Law
}

DOI:

$10.1108 /$ S1059-433720200000084004

\section{Document Version}

Accepted author manuscript

Link to publication record in Manchester Research Explorer

\section{Citation for published version (APA):}

Thornhill, C. (2020). Citizenship, Democracy and the Transformation of Public Law. Studies in Law, Politics, and Society, 86, 69-108. https://doi.org/10.1108/S1059-433720200000084004

\section{Published in:}

Studies in Law, Politics, and Society

\section{Citing this paper}

Please note that where the full-text provided on Manchester Research Explorer is the Author Accepted Manuscript or Proof version this may differ from the final Published version. If citing, it is advised that you check and use the publisher's definitive version.

\section{General rights}

Copyright and moral rights for the publications made accessible in the Research Explorer are retained by the authors and/or other copyright owners and it is a condition of accessing publications that users recognise and abide by the legal requirements associated with these rights.

\section{Takedown policy}

If you believe that this document breaches copyright please refer to the University of Manchester's Takedown Procedures [http://man.ac.uk/04Y6Bo] or contact uml.scholarlycommunications@manchester.ac.uk providing relevant details, so we can investigate your claim.

\section{OPEN ACCESS}




\title{
Citizenship, Democracy and the Transformation of Public Law
}

\begin{abstract}
This article proposes a sociological reconstruction of the emergence of citizenship as a source of legitimacy for political institutions, and it focuses on examining the historical processes that first gave rise to this concept. It explains how citizenship has its origins in the transformation of feudal law, a process that culminated in patterns of military organization that characterized the rise of the early modern state in Europe. On this basis, it describes how the growth of constitutional democracy was integrally marked by the militarization of society and explains that military pressures have remained palpable in constitutional constructions of citizenship. In particular, it argues that, through the early growth of democracy, national citizenship practices were closely linked to global conflicts, and they tended to replicate such conflicts in national contexts. It concludes by showing how more recent processes of constitutional norm formation, based largely in international human rights law, have acted to soften the military dimensions of citizenship.
\end{abstract}

\section{Keywords}

Citizenship; state formation; militarization; democratization; social conflict; human rights

\author{
Contact details \\ Chris Thornhill \\ Professor of Law \\ School of Law, University of Manchester, Oxford Road, Manchester, UK, M13 9PL \\ Email: chris.thornhill@manchester.ac.uk
}

\section{Introduction}

This article examines the concept of national citizenship by assessing the patterns of historical change to which the formation of this concept was originally connected. It shows how the norms implied in citizenship have been constructed through deep-lying social processes, such that they internally refract core structural shifts in society as a whole. On this basis, this article promotes a conceptual-sociological approach to citizenship norms. This approach is focused on examining how deep-lying patterns of social transformation have instilled meanings into theoretical concepts, and it addresses ways in which such meanings remain resonant, often in unforeseen manner, after the formative processes expressed in them lose influence. ${ }^{1}$ It explains that the historical forces that first gave rise to the concept of citizenship have profoundly pre-structured normative expectations attached to citizenship practices in contemporary society. More specifically, it argues that these historical forces have generated deep conflicts and antinomies, which national political systems are required to resolve, and which frequently had the result that political institutions created through citizenship long remained unstable. This article applies these claims, in particular, to the principles of public law promoted by classical constructions of citizenship, and it shows that the historical residues ingrained in citizenship norms have remained palpable through the development of modern public law. These residues have persistently created challenges for national political institutions, and contemporary public law is still defined by endeavours to overcome them. 
To realize these aims, this article explains how the concept of citizenship was formed, first, through the long decline of European feudalism, and, in this context, it underpinned the emergence of modern sovereign states, resulting from processes of territorial consolidation and institutional centralization. It then explains how this concept was consolidated, second, through the emergence of modern standing armies in the long eighteenth century, which was central to the dissolution of feudal social order. In addition, it describes how early concepts of citizenship were translated into core principles of modern public law, such that the legitimational norms that frame the modern state originated in the social conditions that determined the rise of citizenship. In particular, it argues that the legitimational premises of modern public law, in both administrative law and constitutional law, were strongly shaped by the linkage between citizenship formation and military organization. In this respect, this article galvanizes aspects of military sociology to explain the formation of modern law. ${ }^{2}$ The part of modern public law defined as constitutional law, notably, was first formed in the eighteenth century as a body of norms that reflected an image of the citizen that was deeply marked by the military exigencies of early national states, bringing legitimacy to state institutions in procedures originally associated with military mobilization. The fact that early constitutional concepts of citizenship placed a strong emphasis on active participation as a source of legitimacy was shaped by the military functions of the state, and rights of political participation were frequently obtained by citizens as recognition for military service. As a result, this article shows that, in its classical legitimational form, constitutional law tended to establish political systems that both reflected and reinforced the militarization of society that occurred in the late eighteenth century. ${ }^{3}$ That is, early constitutionalism led to the organization of domestic political life on premises determined by war, and it meant that civil political interactions were highly sensitive to behavioural impulses in the military domain. At one level, the rise of constitutional law had the common result that national political practices were influenced by international conflicts, and the procedures by which governments extracted legitimacy from national citizens exposed national political institutions to domestic contestations in a form not fully distinct from inter-state warfare. More generally, the nexus between constitutionalism and militarism created the problem that constitutional movements tended to create political systems in which the institutional order of the state itself appeared as an object of violent rivalry, or even as potential spoils, to be contested between opposed citizenship groups. In early democracies, different groups utilized means of violence to cement their control of the state, and constitutional states typically lost stability as they sought to balance the prerogatives of the rival factions that they internalized. This article explains, thus, that the concepts of citizenship that underpinned early constitutional law were shaped by social forces that did not provide sustainable foundations of legitimacy for national political systems this fact is reflected in the repeated crises of democracy, from 1789 through to 1945. Classical concepts of citizenship imprinted deeply conflictual antinomies in the political systems of national societies, which few democratic polities were able to withstand. In their historical origins, early concepts of citizenship created the basis for the modern state, but, paradoxically, they also failed to establish enduring premises for the legitimacy, or even the stability, of the state that they constructed.

Finally, this article extends its conceptual-sociological approach to examine the processes of norm formation that led, after 1945, to the relative consolidation of constitutional democracy as a globally widespread type of political order. It explains 
that the decades since 1945 witnessed the emergence of a revised concept of citizenship, largely resulting from the global proliferation of human rights law, in which the military elements of constitutional law were weakened, and, distinctively, constitutional law and administrative law tended to converge. Through this, the principles of legitimacy relied on by national polities became partly detached from global conflict, and the historical propensity of domestic polities to be unsettled through the internalization of global conflicts in domestic citizenship practices was diminished. On this basis, the article claims that the essential normative substructure of national democracy - the sovereign national citizen, exercising legislative rights through sovereign state institutions - only became an enduringly secure principle of constitutional legitimacy as it was reconstructed on a transnational normative basis. It was only through this process that the inherent antinomies in citizenship, arising from its historical foundations, were softened.

\section{Citizenship and the foundations of national public law}

National citizenship contains three quite distinct, but also closely overlapping dimensions, each of which is fundamental to the formation of modern nation states and their political institutions. These dimensions cannot easily be treated as fully separate constructions, yet they also conflict with each in certain respects, and they produce, support and legitimate national political institutions in different ways.

Most fundamentally, first, citizenship contains the implication that the citizen of a particular state is entitled to live in a demarcated territory, and, as the condition of such residence, the citizen is subject to certain laws, which are binding on all citizens of the same state, inhabiting the same territorial space. Second, citizenship contains the implication that residency in a particular territory endows the citizen with claims to legal protection for certain rights deemed inherent in human subjectivity. Such rights typically include rights of ownership, rights of personal integrity, and, most importantly, rights to fair and equal treatment before the law.

These two dimensions of citizenship express normative expectations that are closely connected to the long socio-historical process that led from feudal patterns of social organization towards identifiably modern social structures, culminating in the formation of nation states. Central to the normative core of citizenship is the principle that each person is identified as a person under law, and the legitimacy of the law depends on the fact that law is applied to persons in generalized form. The consequence of this is that law founded in recognition of citizens can claim higher authority and greater inner legitimacy than any obligations resulting from purely personal authority; citizenship underpins the existence of an overarching legal/political order, defined by and expressed in generally justified laws, with precedence over familial or other personal status hierarchies. Citizenship thus implies that society itself is a set of legally defined exchanges and interactions, in which - in principle - all persons are equally included. The citizen inhabits a society that is ordered essentially by legal principles, even principles reflecting publicly generalized norms, and the life horizons of the citizen are constructed through laws, to which some expectation of equal enforcement and equal recognition can be directed. As a result, the rise of citizenship is also inextricably linked to the rise of the modern, sovereign state. The formation of the state as an entity able to exercise a relative monopoly of power, to overrule actors possessing historical reserves of private authority, and to claim obedience amongst all members of a national 
society, is not easily thinkable without the normative organization of society around principles of equal citizenship and equal obligation under law (see Gosewinkel, 2016, p. 37 . The immediate legitimational nexus between citizen and government stands at the centre of the modern state, and reciprocal obligations expressed in this nexus for the wellspring of all binding legal norms in society.

On this basis, the third dimension of citizenship appears as the almost inevitable corollary of the first two dimensions. The third dimension of citizenship contains the implication that citizens are entitled to assume, equally, an active role in constructing the legal/political form of modern society, and even to participate in deliberative or electoral processes that confer legitimacy on laws. The precondition of the legitimacy of a law, on this principle, is that citizens understand themselves as freely implicated in its creation. In this respect, early theories of citizenship, represented for example by Locke (1990[1690]), Rousseau (1966[1762]) and Sieyès (1839[1789]), claimed that a legitimate legal-political order, centred around the legislative acts of the modern state, results from the engagement of citizens in making laws, such that laws express the general will of all members of the polity. The original social impetus in the rise of citizenship, which translated social obligations founded in feudal duties into an essentially public system of legal relations, was deeply reinforced by this construction of legitimacy. The positioning of citizens at the law-making centre of society, creating objective conditions for their own citizenship, brought towards conclusion the secular process, formative of modern society, in which social attachments and obligation were placed on generalized foundations. In most societies, the rise of this dimension of citizenship coincided with the removal of the last traces of feudal serfdom.

In these separate layers and dimensions, the concept of citizenship contains two distinct understandings of the ways in which persons in society bring legitimacy to the political systems to which they are obligated and to the laws that bind them. Each understanding is expressed in a distinct construction of the citizen as a holder of rights. On one hand, citizenship implies that all citizens possess a number of personal rights, which preserve persons in society from unwarranted encroachments on legally protected liberties, especially by executors of public authority. On this account, law is legitimated to the extent that it recognizes certain basic attributes of the individual person as demanding protection, and it provides checks to obviate disregard for these attributes by public authorities. On the other hand, citizenship implies that all citizens possess certain public or active rights, the exercise of which allows them to determine the conditions for the use of authority in the society in which they are citizens. On this account, law is legitimated to the extent that it represents collective commitments of persons in society, translating general acts of volition into statutory form. These two aspects of citizenship reflect quite distinct constructions of the essential personality of the citizen. The first understanding indicates that the citizen is, in essence, a singular person. The second understanding suggests that the citizen needs to be conceived, in certain situations, as part of a collective subjective agent, and legitimate laws result from the mediation of personal interests and freedoms into shared, commonly binding undertakings. ${ }^{4}$ In a particular way, these two constructions of the personality of the citizen reflect two different approaches to the transformation of social obligations into public-legal norms during the decline of feudalism. The first construction implies that social obligations acquire public-legal authority if they are proportioned to abstracted individuals. On this account, society itself is an aggregate of singular persons, and law's power to establish 
legitimate public obligations depends on its recognition of persons as single beings with inherently protected interests. Society, accordingly, acquires public legal form through a process of individual recognition. By contrast, the second construction indicates that social obligations obtain public-legal validity if they are created by collective acts of volition. Society acquires public legal form through a process of collective will formation.

The distinction between these two separate aspects of citizenship is sharply reflected in the two primary spheres of modern public law, which, with variations, underpin and define the legitimacy of the political system in most modern national polities. Modern public law first developed through the simultaneous articulation of both aspects of citizenship, and the legal order of most modern governments combines two distinct legitimational principles, founded in these two distinct images of the citizen.

The principle that the citizen is the holder of individual subjective rights is central to the corpus of administrative law in most modern polities. ${ }^{5}$ Administrative law, in general, is a body of legal norms used to regulate public powers that are granted to executive agencies under provisions set out in acts of primary legislation. The essential function of administrative law is to ensure that the agencies and office holders authorized to give effect to statutory legislation act in accordance with the purposes of such legislation, and they do not assume powers not foreseen under the provisions contained in statutes, resulting from primary legislative decisions. Administrative law, in its classical democratic form, was intended to guarantee that the state administration acts as a 'transmission belt' for the realization of statutory purposes (Stewart 1975: 1675). Fundamentally, therefore, administrative law is a part of public law that occupies a mediated, second-order relation to the citizen, and it contains norms that control public functions that do not emanate directly from the will of citizens. It is designed to preserve legitimacy for the political system as a whole by ensuring that the political intentions expressed by citizens, formulated in first-order acts of legislation, are not misrepresented by discretionary acts of persons holding secondary powers.

Importantly, administrative law is often intended to oversee the enforcement of legislation whose meaning is not always explicit. Because of this, administrative law has tended to measure the appropriate application of a law by assessing whether the procedures used to enforce law show due regard for the subjective rights of citizens subject to law. Administrative law has evolved, typically, around the principle that public authority must be applied to citizens in fully warranted and mandated fashion, and any exercise of discretionary powers by public agents must not exceed limits imposed by reasonable interests and expectations on the part of persons subject to power. Accordingly, administrative law implies that a polity acquires legitimacy through the recognition of persons subject to public authority as holders of legally enforceable interests relating to the discharge of public functions. Over time, in most polities, such subjective interests have usually been articulated through constructions of individual rights, which agencies applying publicly elaborated power are obliged to recognize (Jaffe, 1965, p. 475; Schmidt-Aßmann, 2004, p. 15). In this conception, administrative law is required to preserve the legitimacy of the polity by ensuring, not that public agents express the immediate will of citizens, but that they pursue purposes that do not irrationally violate interests that rational citizens are likely to possess. In this respect, administrative law establishes its authority at one remove from the citizen, and it 
projects norms to protect the citizen that are not directly authorized by citizens themselves. In administrative law, the citizen brings legitimacy to law, not, in essence, as law's immediate and original author, but as a person located at the end of law: public authority is observed as legitimate to the extent that it impacts rationally on individual subjects, and the rationality of such impact is commonly assessed by the extent to which due regard is shown for subjective rights. ${ }^{6}$ Overall, administrative law projects a construct of the citizen as an actor positioned outside the order of public power, and its function, primarily, is to regulate powers in which the citizen is not volitionally present. The protection of rights in administrative law is usually reinforced in democratic polities, but it is also possible in polities that fall short of classical measures for defining democracy (see Thornhill \& Smirnova, 2018). In administrative law, the legitimacy of public authority presupposes, not that laws are created by democratically organized citizens, but that they are applied to individual subjects in a manner that appears inherent rational.

The principle that the citizen is the active author of law is central to the corpus of constitutional law in most democratic polities. Constitutional law is conceived as the original expression of the will of citizens, and it draws legitimacy from the assumption that it allows the citizen to remain the present author of legislative acts: constitutional law is conceived, finally, as a normative order to ensure that citizens remain implicated in the creation of laws and the conduct of government. This is the sense of Alexander Hamilton's original claim, in Federalist 78, that a constitution in its entirety is a collection of 'political rights' (Madison, Hamilton \& Jay, 1987[1787-88], p. 437). In each respect, constitutional law constructs the legitimacy of government in terms of its objective immediacy to the citizen. The citizen is recursively present in constitutional law, both as the source of law and as the subject of law, and constitutional law is intended to guarantee the legitimacy of all law by ensuring that it is organically connected to citizens through a chain of legitimational communication (see Böckenförde, 1991, p. 299). Naturally, constitutional law now almost invariably includes recognition of citizens as holders of basic rights, and it typically contains provisions to check the will of the people when this will is exercised in manifest violation of basic rights. In some resopects, such basic rights have grpwn out of the subjective rights originally established in administrative law. It is often noted critically that the protection of rights imposes formal constraints on popular will formation, so that the citizen cannot be fully materialized in constitutional law as active law-giver. This antinomy lies at the common presumption that constitutionalism is in conflict with democracy (Sunstein, 1993; Bellamy, 2007; Webber, 2009). However, since 1918, constitutional law has been pervasively marked by the insistence that a polity is only legitimate if citizens collectively produce laws. Today, typically, restrictions on the capacity of citizens to generate laws are only seen as legitimate if they serve to protect citizens, as law-givers, from collective or majoritarian acts that might weaken democracy itself by reducing the standing of the rights required for effective and inclusive democratic participation (Habermas, 1994). As a result, individual constitutional rights serve, primarily, as objective preconditions for popular will formation, and they are - at least implicitly - willed by the people as a democratic subject, in order to secure and extend the volitional aspect of democracy. In guaranteeing individual rights, constitutions may restrain democratic sovereignty, yet in so doing they retain and in fact reinforce the commitment to the people as an expressive rights-creating subject. Democracy and constitutionalism now usually 
appear in 'an entirely or predominantly mutually supportive relationship' (Walker, 2010, p. 208). Constitutional law, necessarily, is seen as palpably illegitimate if it is not the result of a democratic mandate and if it does not sustain a democratic polity. Modern constitutional law, in consequence, is centred on the assumption that the citizen is part of a sovereign constituent subject, which stands at the beginning of law, and which creates the legal and political forms in which citizenship is exercised (Grimm, 2012 , p. 23). In constitutional law, the legitimacy of law depends on the principle that it reflects - or can be taken to reflect - the reasonable legislative will of all citizens. Even constitutional rights that limit popular will formation are normally intended to ensure that the sovereign will of the people is articulated in fully reasonable, inclusive form.

Public law, in sum, is commonly differentiated into two separate spheres, administrative law and constitutional law. Each sphere of public law is supported by a separate conception of the ways in which citizenship is reflected and brings legitimacy to the polity, and by a separate conception of the preconditions required for the polity to establish binding legal obligations.

\section{Public law and the rise of the modern army}

Despite their distinct normative implications, both spheres of modern public law had the same original societal cause. Both spheres of public law were produced, initially, as responses to phenomena within the military domain of society, and the concepts of citizenship enshrined in administrative law and constitutional law can both be linked to deep-lying changes in processes of military organization. Different parts of public law were determined by the fact that nascent modern states responded to military realities in a range of ways. Each part of public law distilled a specific functional reaction to the transformation of military functions that coincided with the rise of the modern polity.

a. Administrative law and war

The early development of administrative law can be imputed to the increasing formalization of military functions, which impacted deeply on many European states in the late seventeenth and eighteenth century. It was a common hallmark of this period that states established standing armies, of varying magnitude. These standing armies replaced the multi-national mercenary armies which had been deployed in the religious wars resulting from the Reformation. In earlier mercenary armies, military recruits were typically hired by private warlords, and they operated under private arrangements, so that soldiers were bound to perform their duties, not by political loyalty, but by personal oaths and monetary contracts with their regimental leaders, particular to their own military units and regiments (Redlich, 1964, p. 53; Möller, 1976, p. 40). In contrast to earlier mercenary armies, eighteenth-century standing armies were more strictly subject to the control of national regents, and soldiers in such armies were integrated into a fixed legal and administrative organization, in which service obligations were defined in hierarchical form, in codes promulgated by regents and their legal advisors (Burschel, 1994, p. 206; Schmitt, 2007, p. 63; Fichte, 2010, pp. 55, 231). Through the creation of standing armies, most European states witnessed a dramatic expansion in their broader organizational structure, as the subordination of the army to the state administration presupposed the enlargement of the fiscal and judicial capacities of the state. In some societies, the growth of the army and the growth of the state were inseparable, and military bodies assumed duties for the administration of those core civil-political functions that possessed relevance for military growth - 
especially in functions relevant to fiscal extraction. ${ }^{7}$ Tellingly, one leading historian of early modern France observes that it was only in the 1750s that the term 'administration' was used as a generic description of government actions, and the increase in the volume of official functions that led to the employment of this term was closely shaped by military exigencies (Mousnier, 1979, pp. 321, 326).

The expansion of the administrative capacity of national states in the eighteenth century meant that state functions were subject to increasingly codified legal regulation. This was expressed, centrally, in the fact that codes relating to military organization became increasingly uniform (see Frauenholz, 1940, p. 8; Burschel, 1994, pp. 144-45). By the middle of the eighteenth century, military law had been established as a codified part of public law (jus militare publicum), informed by principles of general international law. In many societies, the contractual premises of military mobilization had been systematically integrated into laws concerning public administration. ${ }^{8}$ Alongside this, some basic principles of general administrative law can also be traced to this time, and the codification of military orders and the codification of laws regulating administrative functions did not occur as fully distinct processes. No early modern societies witnessed the separate codification of law relating exclusively to administrative offices; the absence of an internally differentiated political system obviated the drafting of fully specialized legal principles for administrative acts. However, the general tendency towards legal codification in the eighteenth century gave rise, in most polities, to legal codes intended to control official interactions now falling under administrative law. As discussed below, some principles that acquired permanent importance in the development of administrative law were spelled out in legal codes drafted in the eighteenth century. ${ }^{9}$ Increasingly, these codes established the expectation that duties attached to government offices had to be discharged in accordance with pre-defined procedures, entailing the recognition of persons affected by government decisions as bearers of some inherent rights, with accordant entitlement to legal redress in cases of contravention. ${ }^{10}$ This was especially important in the domain of taxation law. Processes of institution building in eighteenth-century Europe were generally marked by the establishment of procedures in which fiscal levies could be subject to review by separate judicial or quasi-judicial bodies. This was reflected emblematically in France, where, by the 1770s, a special department of the Conseil du roi had been created to review appeals regarding taxation and even to enable complaints against royal officials implementing tax directives (see Logette, 1964, pp. 204; Antoine, 2003, pp. 519).

Such codified regulation of administrative functions was especially significant because the growth of the state in the eighteenth century meant that central institutions conducting military and civil administration penetrated into domains previously under the jurisdiction of aristocratic families. This meant that both military and judicial institutions historically managed by actors with seigneurial powers lost influence. This also meant that fewer public duties were discharged by persons claiming offices as patrimony or as benefices. ${ }^{11}$ More generally, the growth of the administrative state was a process in which organizations within the state displaced noble estates as administrative bodies, using formal legal norms to reach into aristocratic territories and bring them under the control of the central state. As a consequence, functions of state were placed on more autonomous foundations, and historically influential social actors, especially in the nobility, were deprived of their traditional constitutional power to influence political decisions. Vitally, the growth of the administrative state was defined 
by the fact that noble estates lost some of their historical power to veto fiscal grants to the government in representative assemblies. In turn, this meant that the constitutional power of the nobility, which depended on the capacity to approve or withhold monetary grants needed for war, was reduced. Instead, the early nation state in Europe was based - almost universally - in the establishment of mechanisms to levy finance through permanent taxes, usually taxes of indirect nature such as levies on sale of goods, so that the constant constitutional support of the nobility was not presupposed for conduct of state affairs, including war. This, then, meant that members of the ancient warrior class - the nobility - lost their historical constitutional role, and the nexus between war and the political constitution of state was weakened. Across Europe, the early modern state evolved as a set of institutions, based in controlled allocation of formal offices, in which the state weakened its constitutional accountability to external actors traditionally required for the supply of war levies and the raising of troops. ${ }^{12}$

It was in this context of deep constitutional transformation that early administrative law first took shape. One vital function of early administrative law was that, in regulating the interactions between government bodies and subjects, it established norms to separate public power from influential private actors, usually in the nobility, who traditionally obtained public office as patrimony. ${ }^{13}$ Moreover, early courts with responsibilities for overseeing administrative offices were widely used to remove jurisdictional powers from ordinary courts, historically attached to the nobility. ${ }^{14}$ More broadly, however, early administrative law was consolidated as part of a technical manoeuvre at the core of the early-modern princely state.

During the period of early modern state formation, on one hand, actors external to the state saw a radical diminution of their constitutional powers. Yet, in parallel to this, inner functions of the state were subject to greater formal scrutiny, and decisions made by public agents were increasingly subject to processes of judicial evaluation and arbitration, so that, in many societies, the state presented its legitimacy as a condition of basic rule-conformity. In most of Europe, indicatively, the rise of administrative law and the administrative state more widely was integrally connected with the rise of natural law, which proposed a concept of legitimacy based in the legal recognition of individual persons subject to power as holders of actionable subjective rights. ${ }^{15}$ In each resect, the rise of the modern state resulted from a dialectical constitutional process. On one hand, it resulted from the individualization of legitimational procedures, which meant that its exchanges with particular persons and parties were bound by increasingly strict protective norms. On the other hand, correlatively, it was marked by the increasing exclusion of collective actors, especially noble estates, from constitutional roles within the state, so that governments could project their legitimacy without reliance on active expressions of social agreement. As indicated, administrative law first developed as a normative order to regulate fiscal contributions. This occurred at the same time that the fiscal sovereignty of the princely state was, to a large degree, separated from procedures for fiscal levying based in aristocratic approval of supply, which tied the state constitution to aristocratic control. In origin, administrative law developed as a legal edifice that included persons in the state in their individual dimension, yet excluded them from the state in their collective dimension.

The early expansion of administrative law was greatly accelerated in the revolutionary period in Europe, between 1789 and 1815. At this time, the military capacities of most 
European states grew exponentially, the number of citizens actively engaged in military duty expanded beyond all precedent, and the density of state institutions increased concomitantly. At this time, in parallel, the local powers of the nobility were either abolished or radically reduced. At this time, then, courts or semi-judicial bodies with responsibility for controlling administrative acts were created in different societies. The assumption that state functions had to be subject to formal regulation became an important means by which states underlined their legitimacy, both towards their citizens and towards other states.

Such intensified formalization of administrative law gained momentum in the French Revolution. For example, in September 1790, provisions for hearing administrative appeals were established in France. These reforms separate administrative procedures from judicial functions, creating the basis for the independent system of $d r o i t$ administratif that later became a feature of French constitutional politics (see Dareste, 1862, pp. 166-69; Laferrière, 1896, pp. 477; Le Yoncourt, 2006). After 1800, administrative appeals in France could be referred to the conseils de préfecture. By 1806, a special section was created in the Conseil d'état (established 1799) to hear administrative litigation. In parallel to events in France, the longer revolutionary era saw the rise of a rudimentary system of administrative law in some German states, which was accelerated by war with Napoleon. ${ }^{16}$ Even in the more autocratic German states, standardization of administrative procedure was actively promoted from circa 1800 (Cancik, 2007, p. 226). Some (variable) protection for individual rights in taxation and police law was established in Prussia in different regulations and edicts, perhaps most notably in 1808 (see Loening, 1914, p. 160; Poppitz, 1943, p. 185; Schrimpf, 1979, p. 66). ${ }^{17}$ In Saxony, such protection was established, in alternative form, in 1835 (Sellmann, 1963, p. 65). Outside Europe, administrative law began to develop in the early American Republic, and early cases heard by the Supreme Court had strong implications for the exercise of powers by administrative bodies (Mashaw 2006: 1338). ${ }^{18}$ Here too, the growth of administrative law was conditioned by war: that is, by 'threats posed by belligerent and powerful foreign states', which acted as a cause of bureaucratic expansion in the early Republic (Mashaw, 2007, p. 1645).

From the eighteenth century onwards, to conclude, periods of intensified militarization inevitably widened the perimeters of statehood, and such periods typically witnessed increasing formalization of administrative law. In its origin, the growth of administrative law was driven by the assumption that public administration, exponentially enlarged in times of war, must be consolidated in stable and reliable form, and it must be separated from private power. Administrative law first took shape around a model of citizenship intended to rationalize, and protect the distinct public quality of, state authority, whose growth was propelled by the expansion of the military system. This model of citizenship coincided with incipient processes of democratization, yet, specifically, it did not implicate the citizen as an internal actor in the creation of public order. In key respects, it located the citizen outside the constitutional order of state. Indicatively, many key advances in administrative law took place after the first period of democratic formation, and they instilled principles of accountability in the state that could be upheld without a democratic constitution.

b. Constitutional law and war 
The development of constitutional law can also be attributed to changing patterns of interaction in the military sphere of society. Importantly, the rise of constitutional law in the revolution of the late eighteenth century began, both in the British colonies in America and in European societies, amidst a crisis in the fiscal apparatus of government. In most instances, this crisis was caused by under-evolved mechanisms for raising public revenue, but it was exacerbated by the escalating monetary burdens placed on governments by the need to maintain standing armies (Neugebauer, 2003, p. 230). American constitutional opposition to British rule was originally a tax rebellion and deep hostility to standing armies was a constant theme in the early development of American constitutional ideas (Mullett, 1966, p. 83; Krumann, 1997, pp. 10, 93). Fiscal weakness was an especially pressing factor in the background to the French Revolution, as the convention of the General Estates that initiated the Revolution was prompted by the Assembly of Notables, which had been summoned to contemplate constitutional solutions for the parlous fiscal position of the Bourbon monarchy (see Egret, 1962, pp. 33-35, 130; Stone, 1986, pp. 5-9). Further, questions of taxation and military spending shaped processes of semi-constitutional reform in European states that did not experience complete revolution in the decades after 1789 (Obenaus, 1980, p. 252). Generally, the broad transformation of statehood in the revolutionary era was connected to the fact that, through the eighteenth century, growing military investment had placed royal executives under intense fiscal strain, which made them susceptible to constitutional overthrow. The constitutional models of citizenship that took shape at this time, then, were intended both to resolve fiscal pressures on governments and to resolve underlying problems of military financing that caused such pressures. The increasing attachment of governmental legitimacy to citizenship practices evolved as an instrument to avert the conflict between fiscal extraction and military financing that unsettled most eighteenth-century states. In consequence, states that were constitutionally reshaped after 1789 devised constructs of citizenship whose essential, if functionally submerged, purpose was both to facilitate revenue extraction and to stabilize the monetary basis of military institutions.

The military significance of citizenship was particularly pronounced in revolutionary France, where the polity based its legitimacy in the projection of the citoyen both as a subject treated equally under law and as an active participant in legislative processes. In this context, the construction of the citoyen was directly formed by fiscal-military pressures. As discussed, the French Revolution resulted from crises caused by the financial requirements of standing armies, and revolutionary politicians partly abolished the military apparatus of the ancien régime. By 1792, however, the Republic was assaulted by the powerful standing armies of major European dynasties, and its leaders were confronted with problems of military financing more pressing than those that afflicted the ancien régime. The figure of the modern citizen evolved in this socioand geo-political constellation. On one hand, the projection of the citizen as a person represented in government helped to establish a more consensual taxation regime, able to generate new revenues for the government, which ultimately survived through the nineteenth century. Additionally, however, this projection had very immediate military implications, and it served to facilitate and expedite the raising of military forces, as rights of active engagement in electoral processes assigned to citizens were made partly conditional on their performance of military duties (Crépin, 2005, p. 87). The military construction of citizenship in early constitutionalism was anticipated as early as December 1789. At this point, Dubois de Crancé proposed a programme of reform for 
the French army that revolved around the assumption that 'every citizen must be ready at all times to march in defence of his country'. ${ }^{19}$ Plans for military reform entailing mass conscription initially encountered opposition, and they were not put into effect. However, this element of the citizenship revolution in France was soon reflected in military obligations imposed by the (unenforced) Jacobin constitution of 1793 , by the levée en masse of 1793, and, finally, by the introduction of mandatory military conscription for men in 1798. In each of these measures, successive revolutionary governments promoted the presumption that the exercise of the active rights and freedoms associated with political citizenship implied acceptance of military obligations. Indeed, these governments attached their authority to their ability to mobilize populations for war, and they predicated their legitimacy on the fusion of an idea of the citizen as political actor with an idea of the citizen as military recruit: the soldat-citoyen (Crépin, 1998, p. 20). This military emphasis was also evident in revolutionary America, where citizenship and military duties partly coalesced (Hippler, 2006, p. 43), reflected in the passing of the Militia Acts of 1792. Analogously, Prussia introduced conscription in 1813-14. Smaller German states also tied citizenship rights to military conscription in the wake of the French Revolution (see Wohlfeil, 1964, pp. 67, 127-29). Generally, the social formation of the citizen as a constitutional actor, which stands at the origins of modern democratic politics, was not easily separable from the social formation of the soldier. For most people, the process that led to citizenship was also a process that entailed becoming a soldier. As discussed, the figure of the citizen evolved as the pivotal principle around which the mass of private obligations typical of feudalism was transformed into a system of legally ordered obligations. This central figure of modern society was originally construed in military form. Indeed, feudalism, itself at core a system of military recruitment, could only be finally superseded as an alternative system of military mobilization was devised. This took shape around the figure of the citizen.

The fact that, from the revolutionary period on, the basic subject of government - the citoyen - was conceived as a military agent whose political rights were correlated with military duties, meant that, in its innermost legitimational core, the state legitimated by the citoyen acquired a military emphasis. The early growth of constitutional government was driven by the principle that the transfer of sovereign power from monarchical executives to national peoples was a requisite of war: constitutional democracy itself, the self-rule of the sovereign nation of citizens, was originally conceived as the self-rule of a people under arms, such that early democracy almost invariably appeared as a system of military rule (see Finer, 2002, pp. 227; Sikora, 2008, pp. 145-46). Subsequently, constitutional democracy remained enduringly centred around the interplay between citizenship and military activities. After 1789, processes of democratization were almost invariably connected to conscription (Krebs, 2006, pp. 184-6). Throughout the nineteenth century, the moments in which electoral participation in government was enlarged were usually directly determined by war and/or by the expansion of military capacities; periods in which governments showed greatest reliance on involuntary military recruits usually led to the broadened allocation of rights of political citizenship. ${ }^{20}$ Emblematically, in the French Third Republic, Europe's most advanced democracy the late nineteenth century, the political rights of citizens were defined as including both the right to vote and the right to be a soldier, which meant that political and military roles were not fully distinct (Hauriou, 1892, p. 676). From the French Revolution onward, in short, the focusing of national 
governments around constitutional democratic citizenship remained inextricably connected to the fact that national governments were centred around military mobilization.

Overall, the two core domains of public law acquired identifiably modern contours in societies of the long revolutionary period, from circa 1750 to 1815. In this period, each part of public law evolved around a distinct concept of citizenship. Constitutional law took shape around the concept of the active citizen, exercising rights of active political participation. At the core of constitutional law was the internalization of the militarized citizen within the state, as a source of legitimacy. Administrative law took shape around a more defensive concept of citizenship, in which the figure of the citizen was used to project rational principles to control the public bodies created and expanded by citizens in their constitutional activities. Early administrative law was intended to articulate inner norms to protect the cohesion of the state, and to ensure that the state could interact with citizens in measured, ordered form. Functionally, this served to translate the production of legitimacy into a constitutional order in which the active exercise of constitutional roles, by constitutional actors with powers attached to military functions, was weakened. The basic principles of public law - namely, that constitutional law places the citizen at the beginning of law, and that administrative law places the citizen at the end of law - emerged as reflections of contrasting reactions in national political systems to the changing realities of war.

\section{Conflicting citizenship practices}

Contemporary public law has generally developed on the premise that democratic polities owe their legitimacy, specifically, to the intensification of the rights of citizens in the constitutional component of public law - that is, by enabling citizens to exercise rights of legislative participation. Accordingly, rights exercised by subjects in administrative law are usually seen to have secondary importance; such rights are perceived as the 'concretized' manifestations of constitutional rights (Werner, 1959, p. 527). To support this, in many polities, the constitutional aspects of public law are expressly observed as having greater force than administrative law, and the citizen acting as a constitutional subject is accorded overriding authority to define the legitimacy of the state. For example, the theory of parliamentary sovereignty in the UK implies that the interests of the subject-citizen defined in administrative law can only be defended if administrative acts are performed ultra vires, beyond powers conferred on the executive by parliament (see Craig, 1998; Elliott, 2001a, p. 23). Likewise, the doctrine of legislative supremacy in France originally expressed a deep contempt for both executive and judiciary. ${ }^{21}$ Critical historical analyses of the Rechtsstaat in Germany often deride the (alleged) tendency in German public law to secure subjective publiclaw rights in the administrative domain without developing a consonantly expansive system of constitutional representation (Vogel, 1980, p. 221; Preuß, 1989, p. 1).

Despite such emphasis on the constitutional element of public law in discussions of democratic legitimacy, it can be widely observed, as a matter of historical record, that most democracies based primarily in principles of active citizenship did not manage to preserve legitimacy over long periods of time. Importantly, in situations in which democratic polities endeavoured to articulate their legitimacy around the active exercise of citizenship, the distinctive military emphasis of citizenship usually proved deeply unsettling. In most such settings, democratic constitutional rule was disrupted 
by the fact that the construct of the active citizen attached domestic political processes to military conflicts, and most domestic polities were unable to withstand the pressures that this induced. In short, the essential constitutional construct of the citizen, around which national governmental institutions were formed and which defined their legitimacy, typically undermined and frequently delegitimated these institutions.

The unsettling impact of the militarized citizen was already evident in the early part of the French Revolution. In this period, as discussed, revolutionary governments attached their legitimacy to the active aspect of citizenship, and citizens were incorporated in the legislative functions of the polity as part of a process in which they were mobilized for national military campaigns. One immediate result of this was that national society as a whole experienced a broad and radical militarization. As citizens were expected to express their membership in the polity by fighting to defend it, they also claimed the right to fight for its domestic constitution, so that violence became a central part of internal political interaction. In this context, discernibly, interstate conflicts resonated very deeply in domestic patterns of political behaviour and institutional consolidation, and war merged into the contest over the terms of governmental legitimacy. The violence associated with the Terror, indicatively, was triggered by fears of invasion and espionage. Rapidly, then, the revolutionary state assumed an extremely authoritarian character, using military personnel to stabilize its position. The French Revolution as a whole was, in essence, a series of military dictatorships (Mathiez, 1973).

The unsettling impact of the militarized citizen became visible, more generally, in the fact that, after the French Revolution, principles of governmental legitimacy were intrinsically defined by success in war. From the early nineteenth century onwards, European states that engaged in international conflict were increasingly likely to collapse because of the outcome of war, and military defeat usually led to regime change. The basic legitimacy of the European state was constructed, in 1789, in terms that were highly sensitive to military activities, and states lost those historical residues of legitimacy that were not premised in triumphant engagement in conflict with other states (Sellin, 2010, p. 105). As legitimacy was attached to effective use of violence, states that could not adequately mobilize for war lost collective loyalty, and they were overthrown.

The unsettling impact of the militarized citizen became tangible, further, in the fact that inner-societal citizenship practices increasingly resembled military conflicts, and domestic political organizations were partly patterned on, or at times not strictly separable from, military units. After 1789 , contest over political power within national societies became a de facto military activity. Groups obtaining power were increasing likely to protect their authority through the extension of warlike contests into civil politics, so that the exercise of governmental office often entailed the full and violent suppression of political opponents. After 1789 , political transitions normally progressed through either low- or high-level civil war, and all governments, whether autocratic or more consensual, solidified their authority through strategies of military repression. This reflected the fact that citizenship was closely linked to violence, and the historical distinction between internal and international conflicts lost some significance. The link between societal militarization and early democracy is also visible in the fact that, in the later nineteenth century, polities that institutionalized higher degrees of political integration for citizens were often the most repressive. For example, by the 1870 s, the 
polity of Imperial Germany was founded in full male suffrage, but growing electoral participation occurred in an environment shaped by military hostility to minorities and political opponents of the state - Jews, Social Democrats, and Poles (Seyferth, 2007, p. 497). As discussed, much the most democratic major polity in nineteenth-century Europe was the Third Republic in France. However, this polity acquired stable form after the mass murder of the organized left, in the Paris Commune. Less militarized polities, such as the UK, were - in telling fashion - less politically competitive and less democratic, at least in electoral terms, than polities in Europe that were more obviously heir to revolutionary democracy.

In each respect, the translation of political legitimacy into a phenomenon resulting from the military integration of the citizen proved deleterious for the longer-term security and legitimacy of political institutions. Perceptibly, in fact, as they extracted their legitimacy from the citizen as actively engaged political participant, national states defined their legitimacy around normative constructs that tended factually to corrode the legitimacy that governments had at their disposal. Constitutional legitimacy itself became a violent, unsettling resource, and the assertion of legitimacy presupposed highly conflictual patterns of societal repression. This was of course widely recognized by sociologists who observed the formation of the modern democratic state at first hand Early sociologists generally viewed the pacification of social conflict as the defining challenge to the integrational capacities of the polity. ${ }^{22}$

The debilitating results of the construction of legitimacy around active citizenship became most acutely manifest in the early twentieth century.

After the revolutionary decades beginning in 1789 , constitutional rule entailing extensive exercise of active citizenship rights survived in very few parts of the globe. Of all revolutionary constitutions created in Europe, none, except the post-revolutionary constitution of Norway (1814), remained in force into the nineteenth century. In 1848, constitutionalism briefly reappeared. However, constitutions written in 1848 that acquired long-term effect initially only enshrined very limited political franchises, and they strategically reduced the norm-constitutive status of the citizen as active member of the polity. For instance, one of the more enduring constitutions created at this time, the Statuto Albertino of Piedmont, which remained the constitutional basis of the Italian state until 1948, established an electoral franchise incorporating less than $2 \%$ of adult males. Ultimately, it was only in the 1860s that constitutional government, involving the attribution of electoral rights to a substantial (albeit still limited) proportion of the adult (albeit still only male) population, became common in Europe. It was not until around the time of World War I, then, that most European polities began to develop political systems in which governments were created under electoral laws that would now be accepted as establishing rights of democratic representation. Of course, democracy was rarely completed in the interwar era, and most post-1918 polities fell short of democracy on a number of counts. For instance, French women could not vote until 1946. Britain retained plural voting until 1950. Germany had a very democratic franchise from 1919 onwards, but, by 1923, the executive branch had institutionalized a system of intermittent rule by presidential prerogative, which became permanent in 1930. In chronological order, Hungary, Italy, Germany, Portugal and Austria subsided into political authoritarianism, of varying degrees of repressive intensity, between 1920 and 1934. Nonetheless, in most European polities, certain basic preconditions of mass 
democracy began to take shape around 1918. Most polities directly impacted by World War I experienced a refocusing of their legitimacy, so that the citizen, as a collectively integrated and active source of law production, was placed squarely at the centre of the governmental order.

In each polity that acquired constitutional form after 1918, the concentration of legitimacy around the construct of the legislatively engaged citizen was fundamentally linked to experiences of military mobilization. The condition of citizenship promulgated in 1918 resulted from processes of societal militarization, in which political citizenship and military conscription were, as after 1789 , very closely associated. In some polities, mass-democratic citizenship was established in 1918 because institutions from the pre1914 period were overthrown by populations organized for war, usually by soldiers in the process of demobilization. This is exemplified by Germany in 1918-19. In some polities, mass-democratic citizenship was established through far-reaching reform of the existing electoral system, designed fully to incorporate all citizens in the exercise of electoral rights as reward for their sacrifices in the war. This is exemplified in the franchise reforms conducted in the UK in 1918. In some polities, mass-democratic citizenship was enlarged to include groups previously marginalized from active citizenship - for instance, women - who had acquired new political relevance through their role in wartime industrial production. This can be seen in many polities, including the Germany, Canada, the USA and the UK (Gullace, 2002; Ross, 2017, p. 149). In each case, military participation was a key determinant in the allocation of citizenship rights. In most polities, further, the widening of electoral rights coincided with a process in which rights to welfare provision were enhanced, and provision for soldiers injured in the war became a cornerstone of emerging welfare systems (see Geyer 1983; Sachße \& Tennstedt, 1988, p. 88; Cohen, 2000, p. 78). The first establishment of material or social citizenship was also driven by war.

Striking in this period of democratic formation, however, is the fact that democracies created around 1918 were brought to crisis because of the particular figure of citizenship to which, constitutionally, they attached their legitimacy. Each polity in the interwar era was profoundly destabilized by the fact that it extracted legitimacy from a model of citizenship that instilled unmanageable degrees of militarization into national society, and into legitimational processes in the national political system. These claims cannot be exhaustively expounded or exemplified here, as different polities were unsettled by the militarization of citizenship in very distinct ways. Nonetheless, three broad tendencies can be identified in the patterns of constitutionalism that came into being around 1918. In each case, the fact that political rights were assumed by citizens at a time when citizenship was defined and realized in recognition of military duties played a central role in engendering political instability.

First, the connection between citizenship and war was reflected in the constitutional order of interwar states because, once released from military duty, citizens often reproduced the attitudes towards command structures that had become established during wartime mobilization. As a result, citizens tended to perceive deep integration in the political system as a premise of political legitimacy. Constitutions created around 1918 frequently reflected this presumption, as they attempted to engage citizens in lawmaking processes, not only as formal holders of political/electoral rights, but as actors authorized to shape legislation and to demand legal recognition in the economic 
dimension of society. Most constitutional orders formed around 1918 contained - either formally or informally - provisions for corporatist integration of the population in economic decision making. Such corporatist provisions were usually based on the models of economic coordination that had developed during World War I, in which trade unions entered close exchanges with state institutions, to ensure effective cooption of the workforce in the war effort (Adler, 1995, p. 90). ${ }^{23}$ On this basis, most post1918 polities endorsed collectivist models of political citizenship, in which economic organizations, such as trade unions and big business groups, assumed representative responsibilities, and political subjects (citizens) entered the state in categories determined by economic memberships, usually linked to class identities. Typically, this intensified integration of the population meant that inter-class conflicts were transmitted immediately through the state, and legislative organs were deeply unsettled by the fact that they acquired heightened obligations for economic management and for balancing interests in industrial conflicts. Most interwar European polities were eventually undone by failure to manage conflicts between the economic groups which they constitutionally internalized around 1918, especially as these conflicts were accentuated in the economic crisis beginning in 1929.24

Second, the connection between citizenship and war was articulated in the fact that post-1918 polities retained the sensitivity to external political conditions and conflicts that had determined their policies during the war, and international pressures were refracted sharply in domestic policies and domestic patterns of political behaviour. This phenomenon acquired particular importance for two reasons. On one hand, this fact assumed importance because most post-1918 democracies integrated population groups who were still partly armed from the war, and who were prepared to use means of military violence to further their own political ends and to shape the form of government (see Gewarth, 2016). In some post-1918 democracies, indicatively, political parties contained their own paramilitary units. On the other hand, this fact assumed importance because the transition to mass democracy in Western and Central Europe occurred shortly after the Bolshevik revolution in Russia, an event that defined the horizon of political affiliation and obligation in most interwar polities. The consequence of this was, in essence, that post-1918 democracies were internally polarized around attitudes to Bolshevism, and lines of political membership, identity and contestation in different European democracies were determined by ideological conflicts of a global nature, originating in the Russian civil war. These factors combined meant that most interwar European polities experienced acute political violence, usually in the form of de facto civil war, between organizations attached to different social classes, some of which supported, and some which were violently opposed to, Bolshevism. In most polities, such conflicts proved intensely destabilizing for political institutions. Most European polities were unable to withstand the acute polarization of political citizenship created by the articulation of global inter-ideological antagonisms with class identities within their own societies.

Third, the connection between citizenship and war was expressed in the fact that in democratic polities in post-1918 Europe institutions of government remained based in military models of organization, and governments retained techniques for engaging with citizens designed during the war. In most societies, the state executive had acquired far-reaching prerogative powers during the period of conflict, and actors in the executive combined with the military to enforce such powers. After armistice, this 
institutional order was widely perpetuated, or re-established, so that, in the context of peacetime democracy, the state preserved formidable executive force. In some post1918 polities, architects of new constitutions argued that the executive should be seen as the core focus of communications between state and citizens, construing democracy as an executive-led political system (Weber, 1988, p. 391). This view was based in the assumption that conflicts between citizens in mass-democratic societies could not be formally mediated, but they could be symbolically managed by powerful executive actors. Some theorists even claimed that executive promulgation of emergency laws was a distinctively legitimate method for representing the combined will of citizens (see Schmitt, 1922). In most post-1918 democracies, however, extensive reliance on emergency legislation became the norm, and emergency laws were routinely used by elite actors to enforce measures not easily compatible with democratic norms, to eliminate economic adversaries from positions of political influence, and even to circumvent normal restrictions on use of military power. ${ }^{25}$ Eventually, most post-1918 democracies were transformed into regimes centred around free-standing executives, armed with far-reaching prerogative authority, and government reverted to a system of social control that was very close to military administration.

In each of these respects, the process, which began around 1789 and became commonplace after 1918, in which the constitutional order of state was transposed onto foundations defined by a strongly participatory construction of national citizenship, usually led to a deep crisis of political legitimacy. Notable in each point above is the fact that democracy first became widespread, around 1918, under conditions of global ideological polarization caused by the Russian Revolution, which expressly defined the defence of class interests as a military conflict. As a result, after 1917, democratic citizenship and class affiliation became very closely aligned, and economic interests represented by rival political groups were strongly linked to parties in the global ideological conflict. Few interwar societies retained democratic systems that were primarily organized around the active aspect of citizenship, and most such democracies were brought to crisis by the essential constitutional terms - the configuration of the citizen - in which they constructed their legitimacy. The principle that citizens should be actively incorporated in the state as authors of law meant that conflicts between citizens assumed a salient position within the state, and this often duplicated global conflicts within the domestic political arena.

\section{Citizenship after civil war: Towards demilitarization}

The period after 1945 saw the beginnings of a socio-historical process, with both practical and normative dimensions, in which democratic political systems gradually obtained greater stability. To be sure, such political stabilization did not occur immediately. After 1945, democracy remained a scarce commodity, which was only elaborated in a small number of polities, mainly in North West Europe. In fact, many states that embarked on renewed democratization processes after 1945 soon suffered reverses similar to those experienced by polities in Europe after 1918. Virtually all governments created through post-1945 democratization processes in Latin America and all governments established through the combination of democratization and decolonization processes in Africa were replaced, initially, by one-party regimes, sometimes with dictatorial features. Moreover, as in the 1920s, the fragility of post1945 democracy was largely connected to global patterns of inter-state or interideological polarization, which meant that the conditions of national citizenship deeply 
refracted global antagonism. After 1945, most states were defined in part by their position in the global ideological conflict between the USA and the Soviet Union, and this frequently had military outcomes for domestic political systems. For example, in Latin America, where states traditionally possessed weak armies with limited capacity for direct civil intervention, the threat of military coup became commonplace, especially after the Cuban Revolution. In this setting, military bodies were frequently deployed to sustain the interests of social groups with strong ideological alignments to the USA. In some Latin American societies, civil war caused by, or closely attached to, global ideological conflict still defines the structure of domestic politics. In such contexts, the form of national citizenship has remained an object of latently military contestation, and this has discernibly prevented the formation of stable political institutions and the consolidation of democratic political processes. ${ }^{26}$ Even in societies, such as the USA, that preserved a predominantly democratic orientation after 1945, the Cold War imprinted a distinctively militarized character on the polity (Sherry, 1995, p. 259; Hogan, 1998, p. $3)$. This was reflected in reinforced concern with national security, in escalating military budgets, and in unprecedented peacetime mobilization of troops. ${ }^{27}$ Overall, the linkage between democratic formation and military politics did not abate in the years after 1945 , and conditions for the construction of robustly legitimational citizenship models remained unpropitious. Some sociologists have even claimed that most societies since 1945 acquired an emphatic military quality (Enloe, 1993, p. 5).

Despite this, however, it is possible to observe certain tendencies in the evolution of national societies after 1945, in which previous proclivities for the uncontrollable militarization of citizenship practices have been diminished. Over a longer period of time, patterns of citizenship and democratic institution building became widespread after 1945, in which political interactions within national societies were partly insulated against pressures in the global domain, and the democratic engagement of citizens could be promoted in procedures that did not expose national institutions, in destabilizing fashion, to inner-societal pressures caused or intensified by global conflicts. By the 1960s, and certainly by the 1980s, the presumption was widely established that democracy should be viewed as the sole legitimate form of government (see Franck, 1992). By 2000, most societies in the world had developed political systems with at least some features of democratic rule. Above all, in this period, it became possible in most societies to integrate citizens in political procedures for democratic representation without exposing institutions to unmanageable social conflicts. Democracy, thus, acquired deep integrational foundations.

There are a number of reasons for this transformation in the institutional substructure of democracy, some of which have little directly to do with legal and political constructions of citizenship. For example, although this is a contested assumption, it is at least arguable that the onset of the Cold War stimulated an increase in welfare provision in different societies, which meant that global conflicts were less likely to inflame class divisions at the national level. ${ }^{28}$ Similarly, at least in Europe, national polities were increasingly bound into normative orders of a supranational nature, in which international goals and alliances were focused, not on war, but on cooperative norm sharing. This tended to promote processes of transnational norm construction that proved beneficial for democracy promotion (Hale, 2015, p. 15). Nonetheless, the attenuation of inner-societal militarization required for democracy can also be attributed to certain changes in the figure of the national citizen itself. In the years after 
1945, many sociologists argued that democratic stability hinged on a revised understanding of citizenship, and it was widely intuited that the basic terms of citizenship were undergoing transformation (see Marshall, 1990[1950]; Parsons, 1965). From a contemporary perspective, however, we can see that the years after 1945 generated patterns of political citizenship, in which - most vitally - the interaction between national and global patterns of norm production lost some intensity and some immediacy. In consequence, citizenship practices in national contexts tended to occur in terms that that did not immediately reflect and replicate global or international antagonisms, and the propensity of national democracies to experience destabilization through their own constructions of legitimacy was diminished.

The transformation of the relation between international conflicts and national political agency resulted, primarily, from the fact that, after 1945, new models of citizenship were endorsed at the global level of society, which modified patterns of citizenship within national societies. After 1945, formatively, a corpus of international law began to take shape that identified the core substance of citizenship as the personal capacity of single agents to claim rights of an essentially individualistic nature. In parallel, such rights were often reproduced and protected in national constitutional orders. Before 1945, protection for individual constitutional rights was rare, and even in polities that possessed Bills of Rights, the justiciability of such rights was not robust. In the years after 1945, by contrast, many national constitutional orders were marked, in a variety of way, by deepening intersection with global patterns of norm formation, so that broader international presumptions in favour of human rights protection affected domestic legal provisions. This was reflected, for instance, in the constitutions of new democracies in Japan (1947), Italy (1948), the Federal Republic of Germany (FRG) (1949) and India (1950), which contained human rights provisions that were closely attached to, or even patterned on, international designs. Most subsequent post-colonial constitutions also assimilated international human rights law in their catalogues of rights. This was reflected, further, in the fact that polities that had retained some basic elements of democracy in the 1930s reinforced existing provisions for basic rights in their domestic constitutions. The decades after 1945 saw the expansion of civil rights and the greater incorporation of the Bill of Rights in the USA. ${ }^{29}$ These decades also saw electoral reforms in the UK, Canada, and, by 1962, Australia, which ensured the equal extension of political rights to all groups.

Overall, in the years after 1945, it is possible to observe a thick and reciprocal interplay between national normative presumptions and global normative presumptions. Polities aspiring to signal their legitimacy in the post-1945 climate were increasingly unlikely not to sanction and reinforce individual rights in their domestic constitutional orders. Self-evidently, such growth in the force of individual rights after 1945 cannot be traced to a strict vertical causal model, in which international norms directly conditioned provisions for rights in all national societies. Internationally proclaimed rights entered national societies in multiple channels, and, in many cases, they only acquired coercive force, where they did so at all, long after 1945. In some polities, notably the FRG and Japan, the protection of basic rights was largely imposed under American administration. ${ }^{30}$ In the USA itself, by contrast, domestic constitutional law was not officially amended after 1945, and - notably - express reliance on international norms in the construction of domestic constitutional rights was very infrequent. As discussed below, however, the importance of the USA in promoting rights globally resonated, at 
least indirectly, in domestic constitutional processes, and constructions of constitutional rights in the USA were progressively aligned to global standards. Importantly, in the period 1945-1964/65, the rights-based model of democracy promoted by America in post-authoritarian societies in Europe and Asia was mirrored in the move away from authoritarianism in the south of the USA itself. ${ }^{31}$ This process saw a number of legal cases brought before the courts that specifically concerned protections for democratic rights. In these cases, the judiciary showed growing willingness to override legislative preferences, especially in matters with implications for rights of minority groups. ${ }^{32}$ Such rulings did not expressly refer to international legal standards. However, they aligned presumptions in favour of Republican rule in American constitutional law to the increasingly fixed global expectation that Republican rule in a political order based in the essentially equal allocation of electoral rights. This period witnessed, in sum, the first tentative emergence of a global polity model, in which, in different ways, human rights acquired a central position. ${ }^{33}$

The transformation of the relation between international conflicts and national citizenship at this time can be seen, first, in its impact on national citizenship practices. The growing focus on human rights meant that citizenship was increasingly construed in relatively static, prior terms: citizenship was defined as a bundle of individual entitlements, which were legally guaranteed as attributes of particular persons. The individualization of rights began, after 1945, in the global domain. Early provisions for international human rights construed rights as guarantees attached to individual subjects, and they were designed to confer protection on persons in states of vulnerability, especially persons threatened by political majorities, hostile communities, military units, or repressive executives. ${ }^{34}$ Subsequently, of course, international human rights law expanded its individualist focus to protect rights accorded to members of particular minority groups and distinct societal communities. This emphatic turn to legal individualization began in the global domain, but it was soon reflected within national polities, when, as discussed, national constitutional principles were widely modelled to reflect, with variations, global principles. Naturally, this does not suggest that, after 1945, international human rights law and national constitutional law did not recognize collective rights. On the contrary, as mentioned, this period typically witnessed the promotion of stricter guarantees for social welfare provision. However, a key implication in the rise of human rights law was that citizens were observed as agents possessing rights, irreducibly, in their capacity as individuals; this fact also underpinned the universalistic design of many post-1945 welfare states. ${ }^{35}$

Through this process, the principle was established that collective expressions of political subjectivity were not essential for the effective assumption of rights, and rights could be presumed and accessed without collective political membership - for instance, in political parties, trade unions, and other political-economic units. This meant, of necessity, that citizenship was less likely to coalesce around the models of associational subjectivity that had traditionally defined the form of modern society, and mobilization of citizenship identities linked to class prerogatives lost some intensity. Moreover, this meant that class-based organizations such as trade unions could more easily be incorporated in national government systems, as class solidarity became less volatile. Even parties of the ultra-left were eventually willing to recognize certain individual rights as separate from class identities, and their members increasingly attached their political initiatives to the use of law and to the protection of rights. ${ }^{36}$ The acceptance of 
singular personal rights played an important role in the partial depoliticization of class affiliations and the creation of constitutional orders able to socialize actors driven by class-defined antagonisms. Indeed, in most stabilizing democracies after 1945, class milieux themselves were subject to processes of increasing individualization, as social agents tended to move more fluidly between roles in a range of organizations, not all embedded in environments shaped by class - these included, for example, religious, educational, political and economic institutions. ${ }^{37}$ Additionally, industrial production processes were frequently organized on less collectivized foundations, ${ }^{38}$ and geographical and work-place mobility became more frequent, especially in societies with deep inter-regional divides (Tolnay, 2003). In consequence of these factors, the classical organizational forms of citizenship became fragmented, and the comprehensive galvanization of different social classes in the form of single political movements became less frequent.

One vital consequence of this individualization of citizenship was that conflicts in the international arena were less intensely correlated with organized subjects in national societies, and national conflicts only exceptionally erupted in binary expressions of inter-group hostility. Subjects within national societies increasingly found support for their claims in individual norms, and direct identification between inner-societal groups and global ideological positions became less frequent. By the mid-1970s, indicatively, many Communist parties in Europe were prompted by their recognition of human rights to sever their links with Moscow, thus reducing the domestic impact of the Cold War and terminating the primary source of domestic constitutional instability in Western Europe (see Brogi, 2011, p. 356). Even as global society became structured by a deep binary fissure, in short, there occurred a striking disarticulation between international politics and national political subject formation. This disarticulation was attached to the emergence of a global legal order that was fundamentally defined, not by inter-ideological conflict, but by individual rights.

The transformation of the relation between international conflicts and national citizenship can be seen, second, in the fact that, owing partly to the global individualization of basic rights, citizens tended to establish organizational forms around claims to rights with a more pluralistic, sectoral emphasis. The increasing declaration of individual rights at the international level coincided, whether by immediate cause or otherwise, by processes in national societies in which persons increasingly sought to exercise citizenship rights in functionally specific dimensions of their lives, so that assertions of citizenship were increasingly identified with sectoral imperatives. In the longer wake of 1945 , national societies frequently divided into multiple patterns of citizenship and political subjectivity, decreasingly focused on prerogatives that overarched all parts of society. After 1945, for example, rights attached to ethnicity were strongly protected, and many stabilizing democracies witnessed an increased concentration of political claims around such rights. Similarly, the protection of rights attached to gender meant that new modes of political subjectivity emerged around reproductive and sexual prerogatives. In some societies, the increasing recognition of medical rights created distinctive patterns of mobilization. ${ }^{39}$ The presumption in favour of a right to peace also created new, intermittently radicalized political subjects. Moreover, political groups tended increasingly to form around educational or environmental interests. The individualization of rights that was generally visible after 1945 led, in many societies, to 
a sectoral or functional differentiation of political citizenship, in which citizenship practices became increasingly attached to localized domains in society. This inevitably meant that cycles of mobilization within national society were less likely to replicate global ideological pressures in mono-centric forms of conflict.

The transformation of the relation between international conflicts and national citizenship was expressed, third, in the fact that, as rights were subject to increasing individual protection, the focus of citizenship practices was less strongly directed towards legislative bodies and the classical legislative emphasis of citizenship lost some centrality. Other organs of public authority, notably courts of law, began to play a more accentuated role as points of focus for demands for rights and general citizenship practices. The power of courts in this regard was often linked to the consolidation of human rights law, both above and within national societies. In many post-1945 societies, core breakthroughs in the formation of citizenship roles were realized, not through legislative acts, but through judicial rulings, and in many cases such rulings were strongly supported by international human rights norms, or at least by globally settled expectations.

Evidence of the expansion of national citizenship through the influence of international law is found in the FRG. By 1958, the Constitutional Court established constitutional rights as part of private law, creating the basis for an expansive model of societal citizenship. ${ }^{40}$ Evidence of this process is found, later, in India, where, by the $1980 \mathrm{~s}$, courts acquired a large share of responsibility for promoting and implementing socialrights legislation. Evidence of this process is found in the UK, a polity traditionally not responsive to international law, where protection for rights of sexual orientation resulted from litigation before an international court. ${ }^{41}$ This is even evidenced, with qualifications, by events in the USA. As discussed, it is often seen as an article of faith in the USA that domestic judicial procedures are firmly closed to international norms. ${ }^{42} \mathrm{As}$ discussed, however, American jurisprudence in the decades after 1945 demonstrated a thickened interaction between international normative presumptions and domestic constitutional law. In fact, domestic patterns of norm construction were tangibly shaped by American security concerns in the Cold War context, and judicial policies were consciously designed to establish rights for marginalized ethnic groups in American constitutional law in order to insulate the USA against external criticism and antagonism. Some early civil rights cases after 1945 reflected arguments that referred expressly to international norms. ${ }^{43}$ An important instance of this is the ruling in Shelley v. Kraemer (1948), ${ }^{44}$ one of the most important of all race-related cases in the USA. In this case, the Executive branch filed amicus curiae briefs that stressed the importance of international law in the fight against selective privileging of citizenship groups (see Elliff, 1987, p. 254; Cleveland, 2006). The expansion of rights of minority citizenship was then reflected paradigmatically in Brown v. Board of Education (1954), for which amicus briefs were also prepared by the Justice Department, referring to the threat posed by racial segregation to American security interests. ${ }^{45}$ The judges who heard this case were very sensitive to the international implications of racial segregation in the USA and very conscious of the resonance of their rulings. ${ }^{46}$ By the $1960 \mathrm{~s}$, as mentioned, domestic constitutional principles were structurally aligned to global norms regarding thresholds of democratic legitimacy, and courts acted against legislative bodies in establishing rights that reflected such thresholds. By this time, internationally accepted principles were assimilated in domestic law in osmotic fashion, as arguments sustained 
on grounds provided by domestic constitutional law were constructed to reflect and to internalize globally sanctioned norms. ${ }^{47}$ On balance, the insistence that American law is closed to international norms results from an exclusively jurisprudential account of judicial findings, and it fails to consider the wider motivational contexts that shape legal decision making. A very narrow and sociologically reductive understanding of the relation between international norms and domestic law is required to deny alignment between national judicial processes in the USA and wider patterns of norm construction. In fact, it is not of material significance whether or not international law was expressly used in this process: proximity between domestic and international law was increased irrespective of actual cause.

One vital outcome of this judicial re-orientation in citizenship was, in different polities, that the interests of citizenship groups were less likely to coalesce around simply mobilized collective subjects. Claims for citizenship were expressed by multiple subjects and directed towards multiple institutions, so that legislative bodies were not required to resolve total demands expressed through social mobilization. To be sure, we can identify situations in different post-1945 societies in which claims for rights have provided the premises for trans-sectoral social mobilization. Human rights campaigns in pre-1983 Argentina and pre-1991 Colombia remain defining examples of this. However, even in such cases, patterns of political mobilization tended to incorporate persons from a range of societal milieux, such that citizens joined in collective actions without forming robustly cohesive collective subjects. ${ }^{48}$ As in other examples discussed above, this differentiation of citizenship also tended to reduce the extent to which conflicts in national societies are simply articulated with global ideological antagonisms. Indeed, in multiplying the number of citizenship forms, this process necessarily disaligned national political practices from simple global conflicts.

In sum, the basic design of democratic citizenship after 1945 was strongly linked to a process in which the traditional tendency for global conflict to replicate itself in immediate, intensified polarities between national citizenship groups was relaxed. of course, conflicts over citizenship rights within national societies were still affected by global conflicts. However, the transposition of global conflicts into national conflicts was rarely reflected in simple bipolar inter-class antagonisms. The USA is again an important - albeit typically rather paradoxical - example of this. From the earlier 1960s onwards, the USA experienced a process of intense inner politicization that was driven to an unprecedented degree by external warfare, as American society as a whole refracted its exposure to war in Vietnam in conditions close to cultural civil war. Indicatively, however, this exposure generated multiple patterns of political mobilization expressing ethnic, sexual, generational, aesthetic, and regional fault-lines in American society. It created a societal environment in which different parties in such conflicts laid claim to rights and articulated their positions around rights, so that a broad range of political groups, establishing multiple inner-societal cleavages, became manifest during the war. ${ }^{49}$ Despite the intensity of such conflicts, however, this did not lead to the binary, class-determined politicization of society. It tended to promote multiple, individualized processes of conflict articulation and ultimate integration, such that global hostilities were not symmetrically replicated in domestic conflict situations.

This paradoxical disalignment between global and national conflict was very largely caused by the fact that a new model of citizenship emerged in the global domain - 
citizenship based in the possession of externally pre-defined single subjective rights. This model was able to displace international conflict as an unmediated stimulant of inner-societal political agency, and, most importantly, it was able to re-direct national political agency towards multiple, parallel patterns of participation, inclusion, and subject formation. Naturally, the rise of human rights law was of itself linked to global ideological tensions. In the USA, as mentioned, the increasing importance of civil rights was partly driven by the force of anti-American propaganda in the Soviet Union. This propaganda aimed to delegitimate the USA both globally and - in particular - in decolonizing societies, where anti-apartheid sentiments were acute, by drawing attention to conditions in the south of the USA close to apartheid in South Africa. ${ }^{50}$ In Europe, the rise of human rights law, and most obviously the ratification of the European Convention on Human Rights (ECHR), can be uncontroversially explained as parts of a stealthy ideological strategy. The ECHR was designed to project distinctive legitimational principles in Western Europe, and to differentiate European polities aligned to Washington from those aligned to Moscow (see Duranti, 2017, pp. 149, 233). Whatever the strategic intentions that brought it into being, however, global human rights law led to a refocusing of the sources of political legitimacy within national societies. It becomes possible, in short, to observe a partial yet pervasive demilitarization of citizenship in the years after 1945, and this eventually set the parameters for the construction of constitutional democracy as an increasingly solid global legal-political form.

\section{Demilitarized citizenship and public law}

In analysing these processes, we can see that the altered emphasis in national citizenship after 1945 modified the relation between the constructs of citizenship that first underpinned the distinct spheres of modern public law - administrative law and constitutional law. As discussed, the core legitimational distinction between administrative law and constitutional law can be seen in the fact that administrative law tend to position the citizen outside the state whereas constitutional law positions the citizen inside the state. In the processes of normative redirection that occurred after 1945, first, the characteristic form of citizenship was shaped by the fact that constitutional law was less strongly dependent for its legitimacy on collective acts of subject formation, and it distilled many social conflicts into disputes over single rights. Underlying this, however, we can observe a process in which constructions of legitimacy particular to the constitutional part of public law began to cede ground to constructions of legitimacy that sustain administrative law. This was of course not a uniform tendency, and it took very different form in different societies. However, this re-orientation in the legitimation of political authority can be viewed in a number of different processes:

First, this shift is visible in the fact that, in many societies, the years after the end of World War II saw a significant expansion of the powers of courts with responsibility for applying administrative law. In some contexts, this led to the effective constitutionalization of administrative law, or even to situations in which administrative law generated constitutional norms. In the USA, this tendency was reflected in the passing of the Administrative Procedure Act (1946), which, building on earlier rulings, ${ }^{51}$ broadened the supervisory scope of the judiciary in administrative matters. This Act is described by one observer as creating a 'constitution for the bureaucracy' (Cane, 2016, p. 90). In the UK, administrative law, created through the 
widening of judicial review as a common-law power, only began to appear as a relatively formalized set of norms in the early 1960s. ${ }^{52}$ Eventually, administrative law assumed particular constitutional significance in the UK, as it was in administrative law that a consistent public-law principle of citizenship was first articulated. It was in this domain that the citizen was first defined as an agent able to impose strict duties on public bodies (Cane, 2016, p. 493). The hardening of constitutional norms in the UK since the 1960s resulted mainly from litigation regarding administrative acts. ${ }^{53}$ Similar cases are found in some common-law jurisdictions, where constitutional norms have been created through judicial rulings with an administrative focus. ${ }^{54}$ In such contexts, governmental legitimacy was increasingly framed by patterns of norm construction based in administrative law.

Second, more broadly, this shift is perceptible in the fact that, especially in Europe, Latin America and Africa, many polities are now locked into strong regional systems of international human rights law. In polities within such systems, both constitutional law and administrative law are strongly focused on concepts of subjective rights, and the divisions between constitutional law and administrative law become uncertain. The underlying principle in regional human rights systems is that, in states party to human rights conventions, human rights law applies directly to individuals, and it is equally binding on the bodies with legislative functions and on the bodies with administrative functions that interact with individual citizens. Such systems project a corpus of overlying norms to regulate and authorize all public acts, with the result that the classical assumption that public bodies are bound by norms originating in national legislation and national constitutional law is weakened. This has particular importance for the relation between constitutional and administrative law; it means that ultra vires cannot be applied as a strict measure of the validity of administrative acts, and the primary gauge of the legitimate administrative act is no longer whether the power exercised in the act originates in a properly constructed piece of legislation. Legislative and administrative acts are both judged by external normative principles, derived from human rights, and all norm-creating acts can be deemed ultra vires if they contravene such principles. ${ }^{55}$ The legitimacy of a public act is determined by whether it rationally justifies its eventual impact on the rights of individual citizens. Regional human rights systems form, in effect, a corpus of transnational law, combining aspects of administrative law and aspects of constitutional law in a regulatory framework that is binding on all public functions in polities integrated into such systems.

In addition, third, this shift is manifest in the fact that procedures and principles originally associated with administrative jurisprudence have assumed a very pervasive role in systems of constitutional law. Indeed, constitutional jurisprudence is now widely formed as a hybrid of classical constitutional principles and classical concepts of administrative law, and the constitutional functions of the state are sometimes legitimated by concepts and criteria extracted from administrative law. In many settings, political institutions classically bound by constitutional law are regulated by principles that place them in a mediated relation to citizens. In such cases, political powers conventionally construed as primary emanations of the will of citizens are governed by norms of public law originally reserved for secondary emanations of the will of citizens, and the expectation that the express will of citizens forms a constitutional premise for legitimate legislation is diminished. 
Indicative of the constitutional importance of principles of administrative law is the fact that perhaps the most globally generalized concept in constitutional law is now the principle of proportionality, which is now used as a constitutional measure of legitimacy in many polities. ${ }^{56}$ The principle of proportionality belongs, in essence, to administrative law, and it was classically applied as a standard to govern institutions exercising second-order powers, typically in societies in which citizens had not yet acquired full democratic rights. ${ }^{57}$ At the core of proportionality reasoning is the presumption that each act of any public agency must recognize the individual person in society as a holder of certain subjective rights. On this basis, any public act that restricts a commonly accepted subjective right can only be condoned if it restricts this right to the minimal degree required to reach a necessary and justifiable objective, serving a clear public interest. When courts conduct proportionality assessment, the legitimacy of a public act is assessed, not primarily by its intrinsic volitional origin, but by the extent to which it reflects a rational correlation between the discretion of the public agent that conducts the act and the sanctioned interests, expectations and rights of the persons affected by it. When applying proportionality, thus, courts can rescind public acts if their impact on subjects in society appears not to be warranted by the weight of the purposes that they promote; in this, courts are effectively enjoined to balance the societal impact of the act against its purpose, and the act can appear illegitimate if the balance struck between purpose and impact appears indicative of weak rationality. Originally, the principle of proportionality was specifically conceived, not as an instrument to measure the legitimacy of public acts by their closeness to will of the citizens, but as a norm to instil rationality and responsibility within the functions of state, and in fact to separate the legitimacy of public office from constitutional actors. ${ }^{58}$

In contemporary society, proportionality is widely used a standard of legitimacy in constitutional law. In the constitutional use of proportionality, the legitimacy of law rests on the degree to which the legislative act that creates it reflects a rational purpose on the part of the legislator, and the rationality of this purpose is typically evaluated by observing whether it affects subjective rights in excessively adverse fashion (see Peterson, 2017, p. 156). This means that, when applying proportionality, courts can correct legislative acts in the same way that they can correct administrative acts displaying unwarranted use of discretion. In many polities, in fact, proportionality does not only form a constitutional measure of law's legitimacy; it also acts to create constitutional norms. In some polities, for example in Canada and Latin America, proportionality has been commonly used in cases where international norms demand intensified protection within domestic political functions, so that in instances where proportionality reasoning is applied international norms obtained elevated constitutional force. ${ }^{59}$ In the UK, proportionality reasoning has been applied in a fashion that clearly alters the constitutional order of the polity. Proportionality contradicts the basic parliamentary principles of the UK constitution, as it implies that public functions can be subject to evaluation by norms not created by parliament itself, insinuating a ground for judicial review not proceeding from considerations of vires. However, since the ECHR assumed direct impact in the public law of the UK in the Human Rights Act of 1998, it has become standard practice for courts to apply principles of proportionality in cases in which human rights - of international provenance - are implicated. ${ }^{60}$ In fact, proportionality reasoning acquired constitutional force in the UK before 1998, as some judges unilaterally elected to apply proportionality in administrative cases with human rights implications. ${ }^{61}$ Overall, the globalization of proportionality implies that 
governmental bodies are increasingly framed as subjects of a legal order marked by close analogy to administrative law, in which, not the substantial will that infuses a law, but its adequacy to rationally justifiable goals is the gauge of law's public authority.

For different reasons, in sum, the fabric of constitutional law is now partly directed by legitimational constructions of the citizen that developed in administrative law. Central to this re-direction is the fact that the original authority of national public law is increasingly imputed, not to the immediate presence of citizens, but to a formal or partly mediated construction of the citizen. As a result of this, increasingly, law's rational impact on individual agents becomes the ultimate measure of its legitimacy, and law can be altered where it fails appropriate rationality tests. What this means - at the deepest level - is that the original function of administrative law, visible in Europe of the ancien régime, has been partly reproduced. A constitutional order has widely taken shape in which public bodies are able to signal legitimacy without the factual integration of constitutional subjects. It has been widely noted that global society as a whole is in the process of evolving a system of global administrative law, mainly focused on transnational social spaces (see Kingsbury, Krisch \& Stewart, 2004; Kingsbury, 2009). However, the globality of administrative law is most strongly expressed in national systems of constitutional law. Indeed, the basic constitutional orders of many national states are subject to the same norms as administrative bodies, and constitutional laws can be changed, without constituent acts, if they impact adversely on reasonable interests in society. Indicatively, constitutional laws in polities as diverse as the UK and Mexico have been altered through litigation before supranational courts, including on proportionality grounds. ${ }^{62}$

This re-orientation from constitutional to administrative models of citizenship is one further reason why the historically unsettling nexus between national and global political contests has been reduced. As it is translated into a co-implied element of a hybrid administrative constitution, national citizenship is less likely to be expressed in single patterns of concerted mobilization and to incorporate global patterns of conflict in national society. Increasingly, in fact, citizenship practices, giving rise to legal recognition and legal change, do not presuppose concerted collective organization, and they can occur in highly individualized procedures, often through acts of litigation. As discussed above, the two elements of modern public law originally assumed form as norms expressing distinct reactions within early national states to institutional pressures caused by war, allowing the state to preserve legitimacy in face of such pressures. In early administrative law, states insulated themselves against historically powerful groups with constitutional authority to authorize law, generating legitimacy by proportioning their activities to an external, rationally mediated construct of the citizen. In constitutional law, states placed the subjects of war - soldiers - at the beginning of law, such that collective conflicts, often expressed in militarized form, became integral to the production of legitimacy. To some degree, the distinction between these two parts of public law has been superseded by emergence of global human rights law, in which law's legitimacy is partly defined, as in administrative law, by its relation to a mediated construct of the citizen. This affects different countries to varying degrees, but only few countries stand absolutely outside the reach of global human rights law, emanating from different sources. On such premises, it is possible for constitutional law to signal its legitimacy - or its rationality - without an immediate relation to citizens, and constitutional laws can be modified and created without 
immediate expression of the will of citizens and without collective conflict over core political decisions. Global norms in fact increasingly enter national society as principles that pacify citizenship practices, replacing the constitutional model of the citizen with the administrative model of the citizen, and they generally soften tendencies towards political militarization.

\section{Conclusion}

The incremental stabilization of democracy that - however precariously - has marked world history since 1945 is linked to a diffuse, pervasive, yet also surprisingly uniform phenomenon. That is, a constitutional form has evolved that alters the alignment between national political interactions and international conflicts, and which reduces the tendency for the basic unit of national democratic practice and legitimation - the citizen - to converge around simple patterns of conflict. Historically, democracy revolved around a concept of citizenship that incessantly disrupted the production of legitimacy for the political system. Historically, in fact, the basic conceptual apparatus of democracy often prevented the emergence of secure democratic institutions. Democracy ultimately acquired more secure form as it developed around a transformation of this conceptual apparatus, reflected in the increasing acceptance that forms of active citizenship, likely to be articulated with strongly collectivized political subjects and to reproduce global conflicts in inner-societal interactions, could not be placed at the legitimational centre of the political system. Central to this reconfiguration of democratic legitimacy production was the rise of a system of individualized human rights, which began in the global domain and spread into national legal systems. Also central to this process was a partial revision of the classical relation between the two core aspects of national public law, administrative law and constitutional law, through which the model of the citizen underlying administrative law became an implied source of legitimacy for national political systems. This revision acquired especial importance in the detachment of national citizenship from global ideological conflicts as it permitted the construction of citizens able to legitimate political institutions without necessitating patterns of conflict resolution requiring deep societal mobilization.

Attempts to reverse this transformation of citizenship, evident in polities today where national citizenship is asserted in strict hostility to global norms, place the fragile normative fabric of this intricately designed democracy at risk.

\footnotetext{
${ }^{1}$ This approach is partly indebted to Reinhart Koselleck's theory of conceptual history and Niklas Luhmann's closely related theory of semantics. Both these theories explain how concepts form aspects of a social structure, which shapes social expectations. But the approach advanced here modifies these approaches as it focuses in particular on the longerterm resonances of historically formed concepts.

${ }^{2}$ In this respect, the article opts for a macro-sociological theory of the pervasion of military principles into patterns of civil institution building. For related endeavours in sociological and historical research see Hintze (1962); Leonhard (2004); Kruse (2017).

${ }^{3}$ One historian construes the essence of modern constitutional citizenship, simply, as the product of social militarization - as 'something born of war' (Kriegsgeburt) (Leonhard, 2004, p. 85).
} 
${ }^{4}$ This was especially implied in the work of Rousseau, who saw the citizen as part of the corporate subject of the people.

${ }^{5}$ See the classical elaboration of the concept of subjective rights in public law in Kelsen (1911, p. 630); Weber (1921/22, p. 387).

${ }^{6}$ The alignment between rationality and recognition of human rights is pervasive even in jurisdictions where human rights do not provide the primary safeguards against executive overreach (see Elliott, 2001b, p. 322).

${ }^{7}$ The primary example of this is Prussia, where military and fiscal offices were closely linked (Jany, 1928, pp. 153, 308-9).

${ }^{8}$ One early compilation of military law defined the jus militare publicum as the 'sum of those laws that define the rights and obligations of territorial regents amongst themselves and between them and their subjects with regard to the conduct of war' (Müller, 1760, p. 13).

${ }^{9}$ See note 66 below.

${ }^{10}$ Exemplary for this is the Prussian Civil Code (Allgemeines Landrecht, 1794 (ALR), which clearly stated that, although collective interests could under some circumstances override some personal rights, the law was to be applied equally to all people (Introduction §22) and personal rights were to be given protection by the state (Introduction §75).

${ }^{11}$ The formation of separate military courts ran parallel to the reduction of aristocratic power over military financing and recruitment (Winter, 2005, p. 202).

12 This process has been extensively covered in much classical sociological and historical research. But for a singularly illuminating analysis see Asch (1999).

${ }^{13}$ For an account of how the very earliest forms of administrative law were used to restrict patrimonialism see Rosenthal (1887, p. 189).

${ }^{14}$ For analysis of one classical example of this process, in France, see Mestre (1999, p. 92).

Generally, before 1789, the growth of courts with administrative jurisdiction involved a reduction in the power of regular courts.

${ }^{15}$ On the deep inner connection between early administrative law and natural law in European states see Voltelini (1910, p. 67); Ogris (1988, p. 43-44).

${ }^{16}$ In post-1789 Prussia, the courts acquired some limited responsibility for administrative regulation. By 1808, a relatively restrictive system was established in which the ordinary courts could exercise some powers of oversight, notably in fiscal and police matters (see Loening, 1914, pp. 160, 188; Sellmann, 1963, p. 50).

${ }^{17}$ Central to this was the Verordnung wegen verbesserter Einrichtung der Provinzial-, Polizei- und Finanz-Behörden (26.12.1808). To a conservative observer in the later nineteenth century, the protection afforded by these regulations appeared 'very encompassing' (Bornhak, 1889, p. 459).

${ }^{18}$ Marbury v. Madison, 5 U.S. 137 has acquired renown as a constitutional law case. But it is also an administrative law case.

${ }^{19}$ Archives Parlementaires (1878, p. 520).

${ }^{20}$ This point is made in Tarrow (2015, p. 241). Examples are the USA after 1865, Germany and France after 1870, and most European polities after 1918.

${ }^{21}$ One historian claims simply that French democracy was founded in a spirit of 'fierce hatred' towards the executive (Roussellier, 2015, p. 544).

${ }^{22}$ Central to Marx's political writings was the claim that modern legal systems contain divergent principles of governmental legitimacy, which cannot be reconciled by peaceful legal means (see Marx, 1958-68 [1844]).

${ }^{23}$ In the USA, labour played a less central role in the coordination of industrial production (see Koistinen, 1997, p. 258).

${ }^{24}$ See my discussion in Thornhill (2011). 
${ }^{25}$ On the Emergency Powers Act (1920) in the UK see Kent (2009: 131). On use of emergency powers in interwar Germany see Feldman (1997, p. 746). In Austria, emergency clauses passed in 1917 remained in force under the 1920 Constitution of the First Republic, and they were used as a basis for reactionary constitutional revision in the late 1920 and early 1930s (see Gürke, 1934).

${ }^{26}$ Colombia can be seen as a classical example of this.

${ }^{27}$ See for discussion Leffler (1992, p. 176); Friedberg (2000, p. 40); Thorpe (2014, p. 15).

${ }^{28}$ See the claim that regime competition between East and West after 1945 triggered welfare investment on both sides in Obinger and Schmitt (2011, p. 265).

${ }^{29}$ See the contrast between positions regarding the incorporation of the Bill of Rights between Adamson v. California, 332 U.S. 46 (1947) and Duncan v. Louisiana, 391 U.S. 145 (1968). Note the claim that the 1960s eventually saw an 'incorporation explosion' (Yarbrough, 1976, p. 258).

${ }^{30}$ On the imposition of a rights regime in the Japanese constitution of 1947, see Hellegers (2001, pp. 189, 500, 503). On American influence in the construction of basic rights in the FRG see Steinberger (1987, p. 34).

${ }^{31}$ For analysis of this process as a democratic transition see Mickey (2015).

${ }^{32}$ See Gomillion v. Lightfoot, 364 U.S. 339 (1960). In Baker v. Carr, 369 U.S. 186 (1962), a case concerning redistricting, litigation began after rebuff by a state legislature (Cortner, 1970, p. 56).

${ }^{33}$ For other expressions of this claim see, with varied emphases, Thomas and Meyer (1984, p. 476); Meyer, Boli, Thomas \& Ramirez (1997). For supporting legal analysis see Simmons (2009).

${ }^{34}$ See for example Hathaway (2005, pp. 4, 24, 53, 75); Partlett (2011, pp. 222-24).

${ }^{35}$ On the international sources of national welfare states after 1945 see Sparrow (2011, p. 44).

${ }^{36}$ See the discussion of the rise of the 'gauche juridique' in the 1970s in Vauchez (2004, p. 60)

${ }^{37}$ For excellent analysis of this process in Germany see Mooser (1983).

${ }^{38}$ On cross-regime tendencies in labour collectivization before 1945 see Patel (2003).

${ }^{39}$ This is clearly visible in South America. See analysis of the case of Bolivia in TorresGoitia Torres et al (2015).

${ }^{40}$ See BVerfGE 7, 198 (1958) - Lüth. This, perhaps the most important case in post-1945 Germany, cited comparative law and international standards.

${ }^{41}$ Smith and Grady v UK (1999) 29 EHRR 493

${ }^{42}$ For declarations in the controversy regarding these points see Dorsen (2005).

${ }^{43}$ For one case involving direct enforcement of international law in American civil rights cases, see Sei Fujii v State (1950), in which a California state appellate court relied on the UN Charter and the Universal Declaration of Human Rights to strike down the state's Alien Land Law, which prohibited a Japanese immigrant from owning land. On appeal, the Supreme Court of California upheld the ruling but did not accept the direct applicability of international law, stating: 'A treaty ... does not automatically supersede local laws which are inconsistent with it unless the treaty provisions are self-executing.' Indicatively for wider subsequent trends in American jurisprudence, the court found instead that the earlier ruling could be supported on grounds provided by national constitutional law, declaring the Alien Land Law 'invalid as in violation of the Fourteenth Amendment': Fujii v. California (38 Cal 2nd 718) 1952.

${ }^{44}$ Shelley v. Kraemer, 334 US 1 (1948)

${ }^{45}$ Brown v. Board of Education of Topeka, 347 U.S. 483 (1954). The Department stated that Brown possessed particular significance because of the international context, in which United 
States was 'trying to prove to the people of the world, of every nationality, race and color, that a free democracy is the most civilized and most secure form of government yet devised by man' (Dudziak, 1988, p. 65).

${ }^{46}$ In 1954, at the same time as Brown v Board of Education, Earl Warren reflected on international politics in the following terms: 'Our American system like all others is on trial both at home and abroad ... the extent to which we maintain the spirit of our Constitution with its Bill of Rights, will in the long run do more to make it secure and the object of adulation than the number of hydrogen bombs we stockpile' (cited in Dudziak, 2004, p. 37).

${ }^{47}$ By the mid-1960s, as discussed, the judiciary played a very active role in establishing conditions for the exercise of equal individual rights, using domestic constitutional provisions to achieve this. In Reynolds v. Sims, 377 U.S. 533 (1964), the Supreme Court declared that it was committed to promoting the 'achievement of fair and effective representation for all citizens'. No direct causal link between national and international norms is imputed here. Yet, such rulings were hand down at the same time that the key international human rights conventions were being debated in the UN (adopted 1966) and that the International Convention on the Elimination of All Forms of Racial Discrimination was adopted (1965).

${ }^{48}$ The writing of the 1991 Constitution in Colombia created fora for different social groups, including different ethnic groups. Human rights mobilization in Argentina was conceived, specifically, as an alternative to class-based mobilization.

${ }^{49}$ For example, on the separation of the black civil rights movement from other protest groups during the Vietnam War see Westheider (1997, p. 85). On the pluralization of political agency at this time see Hale (2011).

${ }^{50}$ See extensive analysis in Lauren (1983); Lockwood (1984); Layton (2000); Skrentny (2002); Borstelmann (2009); Jensen (2016).

${ }^{51}$ See St. Joseph Stock Yards Co. v. United States, 298 U.S. 38 (1936)

${ }^{52}$ See the seminal case Ridge v Baldwin [1964] AC 40

${ }^{53}$ The concept of constitutional rights in UK public law appeared in administrative law. See Attorney General v Times Newspapers Ltd - [1973] 3 All ER 54 (Diplock LJ); Morris v Beardmore - [1980] 2 All ER 753.

${ }^{54}$ In addition to the UK cases above, see Council of Civil Service Unions and others $\mathrm{V}$ Minister for the Civil Service - [1984] 3 All ER 935. See the New Zealand case, Tavita v. Minister of Immigration, [1994] 2 N.Z.L.R. 257 (C.A.),

${ }^{55}$ This is exemplified by the famous UK case before the European Court of Human Rights, regarding protection of sexuality rights in the army, Smith and Grady v UK (1999) 29 EHRR 493. In this case, it was ruled that ultra vires did not provide an adequate standard for assessing executive acts.

${ }^{56}$ Note discussion of the global-constitutional impact of proportionality in Stone Sweet and Mathews (2008); Peters (2017).

${ }^{57}$ The concept of proportionality was first developed, tentatively, in the Prussian ALR. An earlier published draft for the ALR, Allgemeines Gesetzbuch für die preußischen Staaten (1792), contained in $\S 79$ a strikingly modern rights-based concept of proportionality. It stated: 'Laws and ordinances of the state are not allowed to restrict the natural freedom and rights of citizens any more than is required by a collectively beneficial purpose.' This concept gained wider purchase in judgements of the Prussian administrative court (1880 and 1882) regarding limits of police action.

${ }^{58}$ See discussion of background to the rise of proportionality at page XXX above.

${ }^{59}$ See the case in Canada, Slaight Communications Inc v Davidson, [1989] 1 S.C.R. 1038 
${ }^{60}$ See R v Secretary of State for the Home Department, ex parte Daly - [2001] All ER (D) 280 (May). For similar tendencies in the USA see Sullivan \& Frase (2008).

${ }^{61}$ See Bugdaycay v Secretary of State for the Home Department and related appeals - [1987] 1 All ER 940 (Bridge LJ)

${ }^{62}$ In the UK, this occurred in the cases regarding rights of homosexuals discussed at note 64 . In Mexico, the human rights provisions of the constitution were written after criticism in the Inter-American Court of Human Rights generated by rulings inter alia in Case of RadillaPacheco v. Mexico, 23 November, 2009; Case of Rosendo Cantú et al v. Mexico, 31 August 2010.

\section{Bibliography}

Adler, F. H. (1995), Italian Industrialists from Liberalism to Fascism. The Political Development of the Industrial Bourgeoisie, 1906-1934. Cambridge: Cambridge University Press.

Antoine, M. (2003), Le coeur de l'État. Surintendance, contrôle général et intendances des finances 1552-1791. Paris: Fayard.

Archives Parlementaires de 1787 à 1860, Series 1, Volume 10 (1878): 520.

Asch, R. G. (1999), Kriegsfinanzierung, Staatsbildung und ständische Ordnung im 17. und 18. Jahrhundert. Historische Zeitschrift 268, 635-671.

Bellamy, R. (2011), Citizenship. In G. Klosko (ed), The Oxford Handbook of the History of Political Philosophy (pp. 568-99). Oxford: Oxford University Press.

Böckenförde, E.-W. (1991), Staat, Verfassung, Demokratie. Studien zur Verfassungstheorie und zum Verfassungsstaat. Frankfurt am Main: Suhrkamp.

Bornhak, C. (1889), Preußisches Staatsrecht, in 3 vols. Freiburg: Akademische Buchhandlung, vol. 2.

Borstelmann, T. (2009), The Cold War and the Color Line. American Race Relations in the Global Arena. Cambridge, Mass.: Harvard University Press.

Breuer, S. (1983), Sozialgeschichte des Naturrechts. Wiesbaden: Springer.

Brogi, A. (2011), Confronting America. The Cold War between the United States and the Communists in France and Italy. Chapel Hill: University of North Carolina Press.

Burschel, P. (1994), Söldner in Nordwestdeutschland des 16. und 17. Jahrhunderts. Sozialgeschichtliche Studien. Göttingen: Vandenhoeck und Ruprecht.

Cancik, P. (2007), Verwaltung und Öffentlichkeit in Preußen. Tübingen: Mohr.

Cane, P. (2016), Controlling Administrative Power. A Historical Comparison. Cambridge University Press. 
Cleveland, S. H. (2006), Our International Constitution. Yale Journal of International Law $31,1-125$.

Cohen, D. (2000), The War Comes Home. Disabled Veterans in Britain and Germany, 19141939. Berkeley: University of California Press.

Cortner, R. C. (1970), The Apportionment Cases. Knoxville: University of Tennessee Press.

Craig, P. (1998), 'Ultra Vires and the Foundations of Judicial Review.' Cambridge Law Journal 57(1), 63-90.

Crépin, A. (1998), La conscription en débat. Ou le triple apprentissage de la nation, de la citoyenneté, de la République (1798-1889). Arras: Artois Presses Université.

Crépin, A. (2005), Défendre la France. Les Français, la guerre et le service militaire, de la guerre de Sept Ans à Verdun. Rennes: Presses universitaires de Rennes.

Dareste, R. (1862), La Justice administrative en France. France: Auguste Durand.

Dorsen, N. (2005), The Relevance of Foreign Legal Materials in US Constitutional Cases: A Conversation between Justice Antonin Scalia and Justice Stephen Breyer. International Journal of Constitutional Law 3(4), 519-541.

Dudziak, M. L. (1988), Desegregation as a Cold War Imperative. Stanford Law Review 41(1), 61-120.

Dudziak, M. L. (2004), Brown as a Cold War Case. The Journal of American History 91(1), 32-42.

Duranti, M. (2017), The Conservative Human Rights Revolution. European Identity, Transnational Politics and the Origins of the European Convention. Oxford University Press.

Egret, J. (1962), La Pré-révolution Francaise (1787-1788). Paris: Presses Universitaires de France.

Elliff, J. T. (1987), The United States Department of Justice and Individual Rights 19371962. New York: Garland.

Elliott, M. (2001a), The Constitutional Foundations of Judicial Review. Oxford: Hart.

Elliott, M. (2001b), The Human Rights Act 1998 and the Standard of Substantive Review. Cambridge Law Journal 60(2), 301-336.

Enloe, C. (1993), The Morning After. Sexual Politics at the End of the Cold War. Berkeley: University of California Press.

Feldman, G. D. (1997), The Great Disorder. Politics, Economics and Society in the German Inflation 1914-1924. New York: Oxford University Press. 
Fichte, R. (2010), Die Begründung des Militärdienstverhältnisses (1648-1806). Ein Beitrag zur Frühgeschichte des öffentlich-rechtlichen Vertrages. Baden-Baden: Nomos.

Finer, S. E. (2002), The Man on Horseback. The Role of the Military in Politics, new edition introduced by J. Stanley. New Brunswick: Transaction.

Franck, T. M. (1992), The Emerging Right to Democratic Governance. The American Journal of International Law 86(1), 46-91.

Frauenholz, E. von (1940), Das Heerwesen in der Zeit des Absolutismus. Munich: Beck.

Friedberg, A. L. (2000), In the Shadow of the Garrison State. America's Anti-Statism and its Cold War Grand Strategy. Princeton University Press.

Gewarth, R. (2016), The Vanquished. Why the First World War Failed to End, 1917-1923. London: Penguin.

Geyer, M. (1983), Ein Vorbote des Wohlfahrtsstaates. Die Kriegsopferversorgung in Frankreich, Deutschland und Großbritannien nach dem Ersten Weltkrieg. Geschichte und Gesellschaft 9(2), 230-277.

Gosewinkel, D. (2016), Schutz und Freiheit? Staatsbürgerschaft in Europa im 20. und 21. Jahrhundert. Frankfurt: Suhrkamp.

Grimm, D. (2012), Die Zukunft der Verfassung II. Auswirkungen von Europäisierung und Globalisierung. Frankfurt am Main: Suhrkamp.

Gullace, N. R. (2002) “The Blood of Our Sons”. Men, Women and the Renegotiation of British Citizenship during the Great War. Basingstoke: Macmillan.

Gürke, N. (1934), Die österreichische „Verfassung 1934“. Archiv des öffentlichen Rechts 25(2), 178-255.

Habermas, J. (1994), Über den internen Zusammenhang von Rechtsstaat und Demokratie. In: U.K. Preuß (ed), Zum Begriff der Verfassung. Die Ordnung des Politischen (pp. 8394). Frankfurt: Fischer.

Hale, G. E. (2011), A Nation of Outsiders. How the White Middle Class Fell in Love with Rebellion in Postwar America. Oxford: Oxford University Press.

Hale, H. (2015), Patronal Politics. Eurasian Regime Dynamics in Comparative Perspective. Cambridge: Cambridge University Press.

Hathaway, J. C. (2005), The Rights of Refugees in International Law. Cambridge: Cambridge University Press.

Hauriou, M. (1892), Précis de droit administratif, contenant le droit public et le droit administratif. Paris: Larose \& Forcel. 
Hellegers, D. M. (2001), We, the Japanese People. World War II and the Origins of the Japanese Constitution. Stanford: Stanford University Press.

Hippler, T. (2006), Soldats et citoyens. Naissance du service militaire en France et en Prusse. Paris: PUF.

Hintze, O. (1962), Staat und Verfassung. Gesammelte Abhandlungen zur allgemeinen Verfassungsgeschichte, ed. Gerhard Oestreich, 2nd edition. Göttingen: Vandenhoeck \& Ruprecht.

Hogan, M. J. (1998), A Cross of Iron. Harry S. Truman and the Origins of the National Security State, 1945-1954. Cambridge: Cambridge University Press.

Jaffe, L. L. (1965), Judicial Review of Administrative Action. Boston: Little, Brown \& Co.

Jany, C. (1928), Geschiche der königlich Preußischen Armee bis zum Jahre 1802, Vol. I: Von den Anfängen bis 1740. Berlin: Karl Siegismund.

Jensen, S.L.B. (2016), The Making of International Human Rights. The 1960s, Decolonization and the Reconstruction of Global Values. Cambridge: Cambridge University Press.

Kelsen, H. (1911), Hautprobleme der Staatsrechtslehre. Tübingen: Mohr.

Kent, S. K. (2009), Aftershocks. Politics and Trauma in Britain, 1918-1931. Basingstoke: Macmillan.

Kingsbury, B. (2009), The Concept of "Law" in Global Administrative Law. The European Journal of International Law 20(1). 23-57.

Kingsbury, B., N. Krisch \& R.B. Stewart (2004), The Emergence of Global Administrative Law. Law and Contemporary Problems 68, 15-61.

Koistinen, P.A.C. (1997), Mobilizing for Modern War. The Political Economy of American Warfare, 1865-1919. Kansa: University of Kansas Press.

Krebs, R. R. (2006), Fighting for Rights. Military Service and the Politics of Citizenship. Ithaca: Cornell University Press.

Kruman, M. W. (1997), Between Authority and Liberty. State Constitution Making in Revolutionary America. Chapel Hill: University of North Carolina Press.

Kruse, V. (2017), Kriegsgesellschaftliche Moderne. Zur strukturbildenden Dynamik großer Kriege. Cologne: Von Halem.

Laferrière, É. (1896), Traité de la jurisdiction administrative et des recours contentieux, second edition. Paris: Bergher-Levrault, Vol. II. 
Lauren, P. G. (1983), First Principles of Racial Equality: History and the Politics and Diplomacy of Human Rights Provisions in the United Nations Charter. Human Rights Quarterly 5(1), 1-26.

Layton, A.S. (2000), International Politics and Civil Rights Policies in the United States, 1941-1960. Cambridge: Cambridge University Press.

Leffler, M. (1992), A Preponderance of Power. National Security, the Trumann Administration and the Cold War. Stanford: Stanford University Press.

Leonhard, J. (2004), Die Nationalisierung des Krieges und der Bellizismus der Nation. In C. Jansen (ed), Der Bürger als Soldat. Die Militarisierung europäischer Gesellschaften im langen 19. Jahrhundert: Ein internationaler Vergleich (pp. 83-105). Essen: Klartext.

Le Yoncourt, T. (2006), Les attributions contentieuses des corps administratifs sous la revolution. In: G. Bigot \& M. Bouvet (eds), Regards sur l'histoire de la justice administrative (pp. 31-72). Paris: LexisNexis.

Locke, J. (1999[1690]), The Second Treatise of Government, edited by T.P. Pearson. New Jersey: Library of Liberal Arts.

Lockwood, B.B. (1984), The United Nations Charter and United States Civil Rights Litigation: 1946-1955. Iowa Law Review 69, 901-956.

Loening, E. (1914), Gerichte und Verwaltungsbehörden in Brandenburg-Preußen. Ein Beitrag zur preußischen Rechts- und Verfassungsgeschichte. Halle: Verlag der Buchhandlung des Waisenhauses.

Logette, A. (1964), Le comité contentieux des finances près le conseil du roi (1777-1791). Nancy: Société d'impressions typographiques.

Madison, J., Hamilton, A. \& Jay, J. (1987[1787-88]), The Federalist Papers. London: Penguin.

Marshall, T.H. (1992 [1950]), Citzenship and Social Class, introduced by Tom Bottomore. London: Pluto.

Marx, K. (1958-68[1844]), Zur Judenfrage [1844] in Marx \& Engels, Werke, in 43 vols. Berlin: Dietz, Vol. I. pp. 347-377.

Mashaw, J. L. (2006), Recovering American Administrative Law: Federalist Foundations, 1787-1801. Yale Law Journal (115), 1256-1344.

Mashaw, J. L. (2007), Reluctant Nationalists: Federal Administration and Administrative Law in the Republican Era, 1801-1829. Yale Law Journal 116, 1636-1740.

Mathiez, A. (1937), Le gouvernement révolutionnaire. Annales historiques de la Révolution française 80, 97-126. 
Mestre, J.-L. (1999), 'Le traitement du contentieux administratif au XVIII siècle.' La Revue administrative 52(3), 83-97.

Meyer, J.W., Boli, J. Thomas, G.M \& Ramirez, F. (1997), 'World Society and the NationState.' American Journal of Sociology 103(1), 144-181.

Robert M. (2015), Paths out of Dixie. The Democratization of Authoritarian Enclaves in America's Deep South, 1944-1972. Princeton: Princeton University Press.

Möller, H.-M. (1976), Das Regiment der Landesknechte. Untersuchungen zu Verfassung, Recht und Selbstverständnis in Deutschen Söldnerheeren des 16. Jahrhunderts. Wiesbaden: Franz Steiner.

Mooser, J. (1983), Auflösung der proletarischen Milieus: Klassenbindung und Individualisierung in de Arbeiterschaft vom Kaiserreich bis in die Bundesrepublik Deutschland. Soziale Welt 34(3), 270-306.

Mousnier, Roland (1979), 'La fonction publique en France du début du siezième siècle à la fin du dix-huitième siècle.' Revue Historique 261(2): 321-335.

Müller, George Friedrich (1760), Koniglich-Preußisches Krieges-Recht. Berlin: Verlag der Haude- und Spenerschen Buchhandlung.

Mullett, C. F. (1966), Fundamental Law and the American Revolution 1760-1776. New York: Octagon Books.

Neugebauer, W. (2003), 'Staat-Krieg-Korporation. Zur Genese politischer Strukturen im 17. und 18. Jahrhundert.’ Historisches Jahrbuch 123, 197-233.

Obenaus, H. (1980), Finanzkrise und Verfassungsgebung. Zu den sozialen Bedingungen des frühen deutschen Konstitutionalismus. In: B. Vogel (ed), Preußische Reformen 1807-1820 (pp. 244-265). Königstein: Anton Hain, pp. 244-265.

Obinger, H. \& Schmitt, C. (2011), Guns and Butter? Regime Competition and the Welfare State during the Cold War. World Politics 63(2), 246-270.

Ogris, W. (1988), Aufklärung, Naturrecht und Rechtsreform in der Habsburgermonarchie. Aufklärung 3(2), 29-51.

Parsons, T. (1965), Full Citizenship for the Negro American? A Sociological Problem. Daedalus 94(4), 1009-1054.

Partlett, K. (2011), The Individual in the International Legal System. Continuity and Change in International Law. Cambridge: Cambridge University Press.

Patel, K. K. (2003), Soldaten der Arbeit. Arbeitsdienste in Deutschland und den USA 19331945. Göttingen: Vandenhoeck \& Ruprecht, c2003. 
Peters, A. (2017), Proportionality as a Global Constitutional Principle. In: A. Lang \& A. Wiener (eds), Handbook on Global Constitutionalism (pp. 248-264). London: Edward Elgar.

Petersen, N. (2017), Proportionality and Judicial Activism. Fundamental Rights Adjudication in Canada, Germany and South America. Cambridge University Press.

Poppitz, J. (1943), Die Anfänge der Verwaltungsgerichtsbarkeit. Archiv des öffentlichen Rechts 72(2/3), 158-221.

Preuß, U.K. (1989), Perspektiven von Rechtsstaat und Demokratie. Kritische Justiz 22(1), 112.

Redlich, F. (1964), The German Military Enterpriser and his Work Force. A Study in European Economic and Social Policy. Wiesbaden: Franz Steiner, Volume I.

Rosenthal, E. (1887), Die Behördenorganisation Kaiser Ferdinands I. Archiv für österreichische Geschichte 19, 51-316.

Ross, W.G. (2017), World War I and the American Constitution. Cambridge: Cambridge University Press.

Rousseau, J.-J. (1966[1762]), Du contrat social. Paris: Flammarion.

Roussellier, N. (2015), La force de gouverner. Le pouvoir exécutif en France. XIX-XXI siècles. Paris: Gallimard.

Sachße, C. \& Tennstedt, F. (1988), Gescichte der Armenfürsorge in Deutschland, II: Fürsorge und Wohlfahrtspflege. Stuttgart: Kohlhammer.

Schmidt-Aßmann, E. (2004), Das allgemeine Verwaltungsrecht als Ordungsidee. Grundlagen und Aufgaben der verwaltungsrechtlichen Systembildung, 2nd edition. Berlin: Springer.

Schmitt, B. (2007), Armee und staatliche Integration. Preußen und die Habsburgermonarchie 1815-1866. Rekrutierungspolitik in den neuen Provinzen: Staatliches Handeln and Bevölkerung. Paderborn: Schöningh.

Schmitt, C. (1922), Politische Theologie. Berlin: Duncker \& Humblot.

Schrimpf, H. (1979), Die Auseinandersetzung um die Neuordnung des individuellen Rechtsschutzes gegenüber der staatlichen Verwaltung nach 1807. Der Staat 18(1): 59-80.

Sellin, V. (2010), Gewalt und Legitimität. Die europäische Monarchie im Zeitalter der Revolutionen. Munich: Oldenbourg.

Seyferth, A. (2007), Die Heimatfront 1870/71. Wirtschaft und Gesellschaft im deutschfranzösischen Krieg. Paderborn: Schöningh. 
Sherry, M.S. (1995), In the Shadow of War. The United States since the 1930s. New Haven: Yale University Press.

Sieyès, E.J. (1839 [1789]), Qu'est-ce que le tiers-état. Paris: Pagnerre.

Sikora, M. (2008), Die französische Revolution der Heeresverfassung. In: P. Baumgart, B. R. Kroener \& H. Stüble (eds), Die preußische Armee zwischen Ancien Régime und Reichsgründung (pp. 135-163). Paderborn: Schöningh.

Simmons, B.A. (2009), Mobilizing for Human Rights. International Law in Domestic Politics. Cambridge: Cambridge University Press.

Skrentny, J.D. (2002), The Minority Rights Revolution. Cambridge, Mass.: Harvard University Press.

Sparrow, J.T. (2011), Warfare State. World War II, Americans and the Age of Big Government. Oxford: Oxford University Press.

Steinberger, H. (1987), 200 Jahre amerikanische Bundesverfassung Zu Einflüssen des amerikanischen Verfassungsrechts auf die deutsche Verfassungsentwicklung. Berlin: De Gruyter.

Stewart, R.B. (1975), The Reformation of American Administrative Law.' Harvard Law Review 88, 1667-1813.

Stone, B. (1986), The French Parlements and the Crisis of the Old Regime. Chapel Hill: University of North Carolina Press.

Stone Sweet, A. \& Mathews, J. (2008), 'Proportionality Balancing and Constitutionalism.' Columbia Journal of Transnational Law 47, 73-165.

Sullivan, E. T. \& Frase, R.S. (2008), Proportionality Principles in American Law. Oxford University Press.

Sunstein, C. (1993), Constitutions and Democracies: An Epilogue. In: J. Elster \& R. Slagstad (eds), Contitutionalism and Democracy (pp. 327-353). Cambridge: Cambridge University Press.

Tarrow, S. (2015), War, States, and Contention. A Comparative Historical Study. Ithaca: Cornell University Press.

Thomas, G.M. \& Meyer, J.W. (1984), The Expansion of the State. Annual Review of Sociology 10, 461-82.

Thornhill, C. (2011), A Sociology of Constitutions. Constitutions and State Legitimacy in Historical-Sociological Perspective. Cambridge: Cambridge University Press.

Thornhill, C. \& Smirnova, M. (2018), Litigation and Political Transformation: The Case of Russia. Theory and Society 47(5), 559-593. 
Thorpe, R.U. (2014), The American Warfare State. The Domestic Politics of Military Spending. Chicago: Chicago University Press.

Torres-Goitia Torres, J., Torres-Goitia Caballero, J. \& Lagrava Burgoa, M. (2015), La Salud como derecho. Conquista y evaluación en Bolivia. La Paz: Plural.

Tolnay, S.E. (2003), The African American "Great Migration" and Beyond.' Annual Review of Sociology 29, 209-232.

Vauchez, A. (2004), L'institution judiciaire remotivée. Le processus d'institutionnalisation d'une »nouvelle justice« en Italia (1960-2000). Paris: L.G.D.J.

Vogel, B. (1980), Reformpolitik in Preußen. Geschichte und Gesellschaft 6, 202-223.

Voltelini, H. von (1910), Die naturrechtlichen Lehren und die Reformen des 18. Jahrhunderts. Historische Zeitschrift 105(1), 65-104.

Walker, N. (2010), Constitutionalism and the Incompleteness of Democracy: An Iterative Relationship. Rechtsfilosofie \& Rechtstheorie 39(3), 206-33.

Webber, G. (2009), The Negotiable Constitution. On the Limitation of Rights. Cambridge: Cambridge University Press.

Weber, M. (1921/22), Wirtschaft und Gesellschaft. Grundriß der verstehenden Soziologie, edited by Johannes Winckelmann. Tübingen: Mohr.

Weber, M. (1988), Gesammelte politische Schriften. Tübingen: Mohr.

Werner, F. (1959), Verwaltungsrecht als konkretisiertes Verfassungsrecht.

Deutsches Verwaltungsblatt 64, 527-533.

Westheider, J. E. (1997), Fighting on Two Fronts. African Americans in the Vietnam War. New York University Press.

Winter, M. (1999), Preußisches Kantonsystem und ständische Gesellschaft. Frankfurt an der Oder im ausgehenden 18. Jahrhundert. In: R. Pröve \& B. Kölling (eds), Leben und Arbeiten auf märkischem Sand. Wege in die Gesellschaftgeschichte Brandenburgs 1700-1914 (pp. 243-265). Bielefeld: Verlag für Regionalgeschichte.

Wohlfeil, R. (1983), Vom Stehenden Heer des Absolutismus zur Allgemeinen Wehrpflicht. Munich: Bernard \& Graefe.

Yarbrough, T. E. (1976), Justice Black, The Fourteenth Amendment, and Incorporation. University of Miami Law Review 30(2), 231-275. 